This PDF is a selection from an out-of-print volume from the National Bureau of Economic Research

Volume Title: Essays in the Economics of Crime and Punishment Volume Author/Editor: Gary S. Becker and William M. Landes, eds.

Volume Publisher: NBER

Volume ISBN: 0-87014-263-1

Volume URL: http://www.nber.org/books/beck74-1

Publication Date: 1974

Chapter Title: The Behavior of Administrative Agencies

Chapter Author: Richard A. Posner

Chapter URL: http://www.nber.org/chapters/c3630

Chapter pages in book: (p. 215 - 261) 


\title{
The Behavior of Administrative Agencies
}

\author{
Richard A. Posner
}

University of Chicago and National Bureau of Economic Research

Administrative agencies are an increasingly prominent feature of the legal system. This article presents a model of the behavior of such agencies that can be tested empirically and the results of some preliminary empirical tests. ${ }^{1}$ The model is designed to predict how a rational utilitymaximizing agency divides its attention among cases having different characteristics. Part I develops the model, discusses and tests some empirical implications, and compares the implications of the model with alternative models. Part II uses the model developed in Part I as the basis for an empirical examination of a long-standing issue in administrative law - whether combining prosecution and adjudication in the same agency contaminates adjudication.

I wish to express my gratitude to George J. Stigler for his many helpful suggestions. Helpful comments on previous drafts were also made by Gary S. Becker, Kenneth Culp Davis, Owen M. Fiss, Julius G. Getman, William M. Landes, Bernard D. Meltzer, and the participants in the Industrial Organization Workshop of the University of Chicago. The National Bureau of Economic Research provided financial support under a grant from the National Science Foundation for research in law and economics.

1. I use the term "administrative agency" broadly to include any law-enforcement agency whether or not independent of the executive branch of government. The model developed here, however, is limited to the prosecutorial activities of administrative agencies. Much of the analysis is applicable to conventional criminal law enforcement. 


\section{A MODEL OF THE BEHAVIOR OF ADMINISTRATIVE AGENCIES}

\section{A. The Simple Model}

The agency's goal is assumed to be to maximize the utility of its lawenforcement activity. The utility (or more precisely expected utility) of an individual case is the public benefit, if prosecuted successfully, discounted (multiplied) by the probability of successful prosecution. Discounting is required in order to reflect the fact that a case is less worthwhile if, all other things being equal, there is a smaller chance of the agency's winning it." For simplicity, the agency is assumed to bring only two types of cases (the cases within each type being homogeneous) and the number of cases of each type is fixed. Both assumptions are unrealistic but only the second has analytical significance and it will be relaxed later.

The agency maximizes expected utility by investing resources, mostly lawyers' time, in prosecuting violators. The effectiveness of its expenditures in enhancing the probability of successful prosecution and hence utility of a case depends significantly on how much money the defendant decides to spend in defending the case. Most simply,

$$
p=\frac{c}{c+c^{\prime}}
$$

where $p$ is the probability of the agency's winning, $c$ is the agency's litigation outlays, and $c^{\prime}$ the defendant's. If the defendant spends nothing on the litigation, the probability of the agency's winning becomes unity, even if the agency spends very little. If the agency spends nothing, the probability of its winning falls to zero. If both parties spend the same amount, the probability of the agency's winning is 50 per cent.

This formulation is too simple, because it assumes that outcome is a function solely of the ratio of the parties' litigation outlays. If the law is well settled in favor of the agency, or the agency a more efficient litigator

2. The bringing of unmeritorious cases imposes costs on innocent parties, comforts the guilty, and weakens the deterrent effect of the law. Merit is not a dichotomous property and is approximated by the probability of a successful outcome. The model could be altered to recognize that on occasion a case may have value for an agency even if it ends in defeat.

An earlier mathematical model of law enforcement from which I have borrowed is presented in William M. Landes, An Economic Analysis of the Courts, included in this volume. Compare Alan E. Friedman, Note, An Analysis of Settlement, 22 Stan. L. Rev. 67 (1969). 
than the defendant, a smaller expenditure by the agency may have a greater impact on the outcome than a much larger expenditure by the defendant (or vice versa). Equation 1 should be restated as

$$
p=e\left(\frac{c}{c+c^{\prime}}\right)
$$

where $e$ is some factor-it may be a fraction, or it may be larger than one - that measures the effectiveness of the agency's litigation outlays in influencing the outcome of a case in its favor. ${ }^{3}$ If $e$ were 1.5 , it would follow that the agency had a 75 per cent chance of winning when both parties spent the same amount of money on the case. If $e$ were 2 , the agency would have a 67 per cent chance of winning even though the defendant spent twice as much as the agency. However, since $p$ cannot be larger than 1 ,

$$
e<\frac{c+c^{\prime}}{c}
$$

In deciding how much money to invest in each type of case, the agency cannot simply keep spending until a dollar of expenditure no longer increases expected utility by a dollar. It is limited to its appropriation from Congress. A budget constraint must therefore be added to the model.

Equations (4) and (5) summarize the model as thus far developed:

$$
\begin{gathered}
E(U)=a \frac{c_{1} e_{1}}{c_{1}+c_{1}^{\prime}} s_{1}+b \frac{c_{2} e_{2}}{c_{2}+c_{2}^{\prime}} s_{2} ; \\
\\
a c_{1}+b c_{2}=B .
\end{gathered}
$$

$a$ and $b$ are the number of cases of each type; $B$ is the agency's budget; and $s_{1}$ and $s_{2}$ are the agency's gain, expressed in dollars, ${ }^{4}$ from successful

3. A better formulation would probably be $p=\left(c / c+c^{\prime}\right)^{p}$. This would avoid the necessity for a restriction on $e$ (other than $e>0$ ) to prevent $p$ from exceeding unity, and would permit the proportional impact of $e$ on $p$ to vary with changes in $c$ and $c^{\prime}$. James Meginniss has suggested an alternative formulation, $p=e^{c / c}$, where $e$ is the agency's probability of winning when $c=c^{\prime}$, that also has desirable properties. Unfortunately, either formulation greatly increases the computational difficulties of the model, and the gain in realism would not appear to have substantial analytical significance (but see text following note 21 , infra).

4. Although administrative proceedings rarely involve damages or any other readily quantifiable remedy, it is plausible to suppose that an agency ranks its cases, at least implicitly, in accordance with some rough estimate of the dollar equivalent, in public benefits conferred, of a successful prosecution. 
prosecution. The budget constraint is expressed as an equation rather than an inequality in view of the notorious reluctance of government bodies to turn back unused funds to the Treasury.

Clearly, the agency's expenditure on a case is in part a function of how much the defendant spends, and the reverse must also be true - the defendant's expenditure is a function in part of the agency's expenditure. Before we can use equations (4) and (5) to find the agency's optimal expenditure on each case, we must know what the defendant is likely to spend. This requires that we construct a model like equation (5) but from the defendant's point of view.

Assume that, before the litigation, the defendant in a case of the second type had a certain wealth position, $W$. Litigation will produce one of two states of the world. If he wins, his wealth will be diminished only by his litigation expenses; if he loses, his wealth will be diminished by his stakes in the case as well. By discounting each state by the probability of its occurrence, we can express his wealth position after litigation $\left(W^{\prime}\right)$ as follows:

$$
W^{\prime}=\frac{c_{2}^{\prime} e_{2}^{\prime}}{c_{2}^{\prime}+c_{2}}\left(W-c_{2}^{\prime}\right)+\left(1-\frac{c_{2}^{\prime} e_{2}^{\prime}}{c_{2}^{\prime}+c_{2}}\right)\left(W-s_{2}^{\prime}-c_{2}^{\prime}\right) .
$$

The first expression on the right-hand side of the equation $\left(c_{2}^{\prime} e_{2}^{\prime}\right) /$ $\left(c_{2}^{\prime}+c_{2}\right)$ is the probability $\left(p_{2}^{\prime}\right)$ that the defendant will win rather than the agency. It should be emphasized that $e_{2}^{\prime}$ (and therefore $p_{2}^{\prime}$ ) like $e_{2}$ (and therefore $p_{2}$ ) is a subjective term: it is the defendant's estimate of the effectiveness of his expenditures on the outcome of the suit. The parties may have inconsistent estimates. Indeed, as we shall see, without such differences there would be few litigated cases.

The defendant is assumed to operate without a budget constraint. Unlike the agency, he can hire additional legal resources until their marginal product falls to zero.

The reader may wonder why the stakes for the defendant, $s_{2}^{\prime}$, are distinguished from the stakes for the agency in the same case, $s_{2}$. The reason is that they may not be identical. A clear instance of asymmetry is presented by any monopoly case: the social costs of monopoly exceed the private benefits to the monopolizer. ${ }^{5}$ To take another example, an

5. The monopolist who cannot discriminate perfectly in price maximizes profits by selling a smaller quantity at a higher price than under competition. His gain - the difference between the monopoly and the competitive price multiplied by the number of units soldis also a loss to the purchasers of this output. Another loss, which the monopolist does not capture, is the loss to those consumers whom the higher, monopoly price deters from continuing to buy the monopolist's product, and who substitute other products that cost more, or are otherwise less desirable, than the monopolist's product when sold at a competitive price. 
order forbidding the mailing of a type of advertising brochure found to be deceptive may be much more costly to a defendant who has already had the brochure printed than to a defendant who has not, yet the order against the second defendant is just as valuable to the agency as the order against the first. Furthermore, an order may have importance to an agency beyond any effect in abating the defendant's illegal conduct: as a precedent. Precedent has a dual significance. It makes it easier for the agency to win the next case (if a similar case), and it may deter others from engaging in like conduct. The dismissal of a case will lack comparable significance to the defendant unless he anticipates frequent future encounters with the agency ${ }^{6}$ Finally, since the benefits of administrative proceedings frequently cannot be quantified, the agency's implicit valuation of the fruits of a successful prosecution may differ substantially from the costs to the defendant.

The first derivative of $W^{\prime}$ with respect to $c_{2}^{\prime}$ is

$$
\frac{d W^{\prime}}{d c_{2}^{\prime}}=\frac{c_{2} s_{2}^{\prime} e_{2}^{\prime}}{\left(c_{2}^{\prime}+c_{2}\right)^{2}}-1
$$

By setting the derivative equal to zero and solving for $c_{2}^{\prime}$, we can discover how much money a defendant in our second type of case should spend in order to maximize his wealth. That expenditure is

$$
c_{2}^{\prime}=\sqrt{c_{2} e_{2}^{\prime} s_{2}^{\prime}}-c_{22}
$$

which implies, not unrealistically, that if the defendant's stakes are relatively small, an increase in $c_{2}$ will induce him to reduce his expenditure on the case, while if they are relatively large, it will induce him to increase it. $^{\text {? }}$

We may now return to equation (4) and determine the utility-maximizing expenditure of the agency on the same case. By substituting equation (8) into equation (4), solving equation (5) for $c_{1}$ and substituting the

6. Such asymmetry is not limited to public law enforcement. In accident litigation, for example, the usual defendants - insurance companies - have an interest in precedent that is not shared by the accident claimants. Some evidence on the significance of this asymmetry is presented in Richard A. Posner, A Theory of Negligence, 1 J. Leg. Studies 29, 94-96 (1972).

7. The rate of change of $c_{2}^{\prime}$ with respect to $c_{2}$ is

$$
\frac{\partial c_{2}^{\prime}}{\partial c_{2}}=\frac{\sqrt{e_{2}^{\prime} s_{2}^{\prime}}}{2 \sqrt{c_{2}}}-1 .
$$

This expression is negative (signifying that an increase in $c_{2}$ will cause a decrease in $c_{2}^{\prime}$ ) when $s_{2}^{\prime}$ is relatively small, and positive when it is relatively large. 
result into equation (4), and simplifying, we can restate equation (4) as follows:

$$
E(U)=\frac{\sqrt{a} e_{1} s_{1} \sqrt{B-b c_{2}}}{\sqrt{e_{1}^{\prime} s_{1}^{\prime}}}+b s_{2}\left(\frac{c_{2} e_{2}}{\sqrt{c_{2} e_{2}^{\prime} s_{2}^{\prime}}}\right)
$$

The first derivative of $E(U)$ with respect to $c_{2}$ is

$$
\frac{d E(U)}{d c_{2}}=\frac{b s_{2} e_{2}}{2 \sqrt{c_{2} e_{2}^{\prime} s_{2}^{\prime}}}-\frac{b e_{1} s_{1} \sqrt{a}}{2 \sqrt{e_{1}^{\prime} s_{1}^{\prime}\left(B-b c_{2}\right)}} .
$$

By setting the derivative equal to zero and solving for $c_{2}$ we discover that the expenditure by the agency on type 2 cases that maximizes the agency's utility is

$$
c_{2}=\frac{B s_{2}^{2} e_{2}^{2} s_{1}^{\prime} e_{1}^{\prime}}{a s_{1}^{2} e_{1}^{2} s_{2}^{\prime} e_{2}^{\prime}+b s_{2}^{2} e_{2}^{2} s_{1}^{\prime} e_{1}^{\prime}} .
$$

An objection to this method of determining the agency's optimum expenditure is that while the agency, in deciding how much to spend on prosecuting a case, takes account of the fact that the defendant's expenditure is a function in part of how much the agency spends, the defendant takes the agency's expenditure as given - he does not consider how the agency might react to a change in his expenditure. The asymmetry is not entirely unrealistic. The position of the parties is asymmetrical. The agency is the moving party in the litigation and controls to a considerable extent its timing and scope. The agency presumably has greater experience with respect to the particular kind of litigation involved than a defendant who appears infrequently before it, although this disparity may be offset to the extent that there are private lawyers who specialize in litigation before the particular agency. Finally, the agency is a bureaucracy in which decisions and procedures presumably tend to be routinized. These factors make it somewhat plausible that the agency, in deciding what to spend on a case, will make a rough estimate of the defendant's likely expenditures (viewed in part as a function of its own expenditures) and the defendant will adjust to the level of the agency's expenditures. If the defendant were assumed to have the same reaction function as the agency's in the model, the optimum expenditure of both parties would be indeterminate. $^{8}$

8. This indeterminacy resembles that encountered by attempts to determine an oligopolist's optimum price when he is assumed to act independently but to take account of his rivals' reactions to his price changes. See George J. Stigler, The Theory of Price 217-19 (3d ed. 1966), for a succinct discussion of the problem. An alternative approach to the 
For understanding how changes in the characteristics of the agency's two types of cases alter the allocation of resources between them, the ratio between $c_{2}$ and $c_{1}$ is helpful:

$$
\frac{c_{2}}{c_{1}}=\frac{s_{2}^{2} e_{2}^{2} s_{1}^{\prime} e_{1}^{\prime}}{s_{1}^{2} e_{1}^{2} s_{2}^{\prime} e_{2}^{\prime}}
$$

If $B, a$, and $b$ are assumed to be constant any increase in $c_{2}$ must result in a decrease in $c_{1}$, and vice versa. If the agency's stakes $\left(s_{1}\right.$ and $\left.s_{2}\right)$ are also held constant, then it is clear from equation (12) that $c_{2}$ will fall and $c_{1}$ rise if the effectiveness of the agency's expenditures falls in cases of the second type or rises in cases of the first type; if the effectiveness of defendants' expenditures falls in cases of the first type or rises in the second type; or if defendants' stakes rise in the second type of case or fall in the first type.

These factors are independent of the social benefits of successful prosecution of type 2 cases. Even if those benefits are great - let us henceforth assume that $s_{2}$ is much larger than $s_{1}$-they may be overwhelmed by other factors that a rational utility-maximizing agency must take into account. It is plausible, moreover, that $e$ will be higher in a class of relatively minor violations and $s_{1}^{\prime}$ smaller in relation to $s_{1}$ than $s_{2}^{\prime}$ in relation to $s_{2}$. The explanation has to do with precedent. The public benefit from proceeding against a violation may be relatively small because the law is so well settled that the case will have little importance as precedent. Precisely because the law is well settled, however, the probability of successful prosecution, even without a large expenditure of resources, is probably high. The rational agency will be especially attracted to cases that have importance as precedent but in which the monetary stakes are small. The usual defendant is uninterested in whether the outcome of his case will have precedential significance. Since it would be surprising if the precedential significance of a case increased in proportion to the monetary stakes, $s_{1}^{\prime}$ is likely to be smaller relative to $s_{1}$ than $s_{2}^{\prime}$ to $s_{2}$.

A frequent criticism of administrative agencies is that they mis-

oligopoly problem, and one with some relevance in the present context, is to treat it as a problem of collusive rather than of independent action. See George J. Stigler, A Theory of Oligopoly, 72 J. Pol. Econ. 44 (1964), reprinted in George J. Stigler, The Organization of Industry 39 (1968); Richard A. Posner, Oligopoly and the Antitrust Laws: A Suggested Approach, 21 Stan. L. Rev. 1562 (1969). Like oligopolists, litigants can increase their wealth by agreeing to limit their rivalry, and specifically by agreeing to reduce their expenditures on litigation. Agreements to stipulate rather than litigate facts are a common example - but of this more later. 
allocate their resources by bringing mostly small cases. ${ }^{9}$ But our model suggests that under plausible assumptions concerning the characteristics of the agency's cases, a perfectly rational, utility-maximizing administrative agency will devote a "disproportionate" amount of its resources to relatively minor cases. Let $s_{1}$ and $s_{1}^{\prime}$ be $\$ 10, e_{1} 2, e_{1}^{\prime} .9, s_{2}$ and $s_{2}^{\prime} \$ 40, e_{2} 1.5$, $e_{2}^{\prime} 1, a 20, b 5$, and $B \$ 50$. Solving equation (11) for $c_{2}$, and (3) and (8) for $c_{1}, c_{2}^{\prime}$ and $c_{1}^{\prime}$, we discover that the agency should spend $\$ 3.36$ on each case of the second type and $\$ 1.66$ on each case of the first type. (The defendant's optimum expenditure is found to be $\$ 8.44$ in a case of the second type and $\$ 2.14$ in a case of the first type.) Although the aggregate social benefits from cases of each type (i.e., $a s_{1}, b s_{2}$ ) are equal $-\$ 200-$ the agency devotes two-thirds of its resources to cases of the first type. And although each type 2 case involves four times the social benefits of each type 1 case, the agency spends only twice as much money litigating each case of the former type. This is optimizing behavior rather than a manifestation of stupidity or timidity. The agency's utility would be less if it allocated additional monies from its limited budget to the larger cases.

One factor inducing the agency to devote so many resources to cases of the first type is the higher rate of success in such cases that it anticipates. Another, and related, factor is defendants' relative pessimism about such cases $\left(e_{1}^{\prime}\right)$. A similar effect would also result if $s_{2}^{\prime}$ were higher than $s_{2 .}$, as our earlier analysis suggests it might well be.

Substituting the results of our numerical example into equation (2), we discover that the agency expects to win 87 per cent of its type 1 cases but only 43 per cent of its type 2 cases. The defendants' expectations are inconsistent with the agency's. To determine the objective probability of the agency's winning let us assume that the parties are equally good (or bad) estimators so that the true figure $(\dot{p})$ is the mean of their predictions. Thus,

$$
\dot{p}_{1}=\frac{p_{1}+1-p_{1}^{\prime}}{2},
$$

from which we can determine that the agency will win 68 per cent of its type 1 cases and 36 per cent of its type 2 cases.

Table 1 presents some additional numerical examples. The last column summarizes the example in the text.

9. See, e.g., ABA Comm'n to Study the Federal Trade Commission, Report, p. 1 (Sept. 15, 1969); Commission on Organization of the Executive Branch of the Government (Hoover Commission), Appendix N, Task Force Report on Regulatory Commissions 119 (Jan. 1949); Philip Elman, Administrative Reform of the Federal Trade Commission, 59 Georgetown L.J. 777, 778 (1971). 
TABLE 1

Examples of Different Optimum Expenditures

\begin{tabular}{|c|c|c|c|c|c|c|}
\hline & $\begin{array}{l}\text { Hypo- } \\
\text { thetical } 1\end{array}$ & $\begin{array}{l}\text { Hypo- } \\
\text { thetical } 2\end{array}$ & $\begin{array}{l}\text { Hypo- } \\
\text { thetical } 3\end{array}$ & $\begin{array}{c}\text { Hypo- } \\
\text { thetical } 4\end{array}$ & $\begin{array}{l}\text { Hypo- } \\
\text { thetical } 5\end{array}$ & $\begin{array}{c}\text { Hypo- } \\
\text { thetical } 6\end{array}$ \\
\hline & \multicolumn{6}{|c|}{ Independent Variables } \\
\hline$s_{1}(\$)$ & 10 & 10 & 10 & 10 & 10 & 10 \\
\hline$s_{i}^{\prime}(\$)$ & 10 & 10 & 10 & 10 & 10 & 10 \\
\hline$e_{1}$ & 1 & 1 & 2 & 2 & 2 & 2 \\
\hline$e_{1}^{\prime}$ & 1 & 1 & .9 & .9 & .9 & .9 \\
\hline$s_{2}(\$)$ & 40 & 40 & 40 & 40 & 40 & 40 \\
\hline$s_{2}^{\prime}(\$)$ & 40 & 80 & 50 & 50 & 40 & 40 \\
\hline$e_{2}$ & 1 & 1 & 1.7 & 1.7 & 1.8 & 1.5 \\
\hline$e_{2}^{\prime}$ & 1 & 1 & 1.1 & 1.1 & 1.1 & 1 \\
\hline$a$ & 20 & 20 & 20 & 20 & 20 & 20 \\
\hline$b$ & 5 & 5 & 5 & 5 & 5 & 5 \\
\hline \multirow[t]{2}{*}{$B(\$)$} & 50 & 50 & 50 & 60 & 60 & 50 \\
\hline & \multicolumn{6}{|c|}{ Dependent Variables } \\
\hline$c_{2}(\$)$ & 5.00 & 3.33 & 3.11 & 3.74 & 4.78 & 3.36 \\
\hline$c_{2}^{\prime}(\$)$ & 9.15 & 13.01 & 9.97 & 10.61 & 9.37 & 8.44 \\
\hline$c_{1}(\$)$ & 1.25 & 1.67 & 1.72 & 2.07 & 1.81 & 1.66 \\
\hline$c_{1}^{\prime}(\$)$ & 2.28 & 2.43 & 2.21 & 2.25 & 2.23 & 2.14 \\
\hline$a c_{1}(\$)$ & 25 & 33.73 & 34.45 & 41.30 & 36.10 & 33.20 \\
\hline$b c_{2}(\$)$ & 25 & 16.67 & 15.55 & 18.70 & 23.90 & 16.80 \\
\hline$p_{2}(\%)$ & 35 & 20 & 40 & 44 & 61 & 43 \\
\hline$p_{1}(\%)$ & 35 & 41 & 88 & 96 & 90 & 87 \\
\hline$\dot{p}_{2}(\%)$ & 35 & 20 & 28 & 31 & 44 & 36 \\
\hline$\dot{p}_{1}(\%)$ & 35 & 41 & 68 & 74 & 70 & 68 \\
\hline
\end{tabular}

B. Empirical Implications and Alternative Models

Our model has several testable implications. Among them:

1. An agency will probably devote relatively greater resources, in the aggregate, to small cases (as measured by the stakes) than to large.

2. However, it will devote more resources to each large case than to each small one.

3. The dismissal rate will probably be different in different types of cases and lower in the larger cases.

4. The average dismissal rate across all classes of case need not tend toward 50 per cent and may well be lower. 
Tables 2 and 3 use data relating to the Federal Trade Commission in a preliminary test of these implications. The results in Table 2, which shows how the FTC allocates its budget among its three classes of case (antitrust cases, deceptive-practice cases, and textile and fur cases), are consistent with the first and second implications. The FTC devotes about one-third as many resources to textile and fur cases as to all other labeling and advertising cases. And it devotes roughly as many resources to all advertising and labeling cases as it does to antitrust, although virtually everyone believes that the Commission's antitrust work involves potentially much greater social benefits than its efforts to prevent mislabeling and false advertising. The ratio of resources devoted to textile and fur cases to resources devoted to antitrust is particularly striking. ${ }^{10}$ At the same time the Commission spends more than five times as many resources on the average antitrust case than on the average textile or fur case.

Textile and fur cases are brought under special statutes ${ }^{11}$ that require little evidence to establish a violation. In addition, the stakes in such cases are typically small. In our terminology, $s$ and $s^{\prime}$ (the agency's and the defendant's stakes, respectively) are low; $e$ (the effectiveness of the agency's expenditures in procuring an outcome favorable to it) is high; and $e^{\prime}$ is low. All of these factors work to reduce $c$, the agency's optimum expenditure per case, while the high $e$ and low $e^{\prime}$ make these cases, as a class, relatively more attractive to the agency (assuming it to be a rational utility maximizer) than cases in which the difficulties of establishing a violation are greater. This explains why the expenditure per textile and fur case is low but the aggregate expenditure on the class of these cases high relative to their importance.

Table 3, which compares the dismissal rate in the FTC's antitrust cases with the dismissal rate in all of its cases, supports the third and fourth empirical implications of our model. The dismissal rates in different classes of cases are different; they do not average out to 50 per cent; the

10. The ratio of big to little FTC cases is actually overstated in Table 2, since the antitrust category includes the minor provisions of the Robinson-Patman amendments to the Clayton Act, 15 U.S.C. $\$ \S 13$ (c), (d), and (e) (1970). On the propensity of both the FTC and the Antitrust Division of the Department of Justice to emphasize minor violations, see Richard A. Posner, The Federal Trade Comission, 37 U. Chi. L. Rev. 47 (1969); Richard A. Posner, A Statistical Study of Antitrust Enforcement, 13 J. Law \& Econ. 365 (1970). For some other evidence consistent with the implications of the model see id. at 381 (table 11), 382 (table 12); Table 8, infra.

11. Wool Products Labeling Act, 15 U.S.C. $\$ 68$ (1970); Fur Products Labeling Act, 15 U.S.C. $\$ 69$ (1970); Textile Fiber Products Identification Act, 15 U.S.C. $\$ 70$ (1970). 


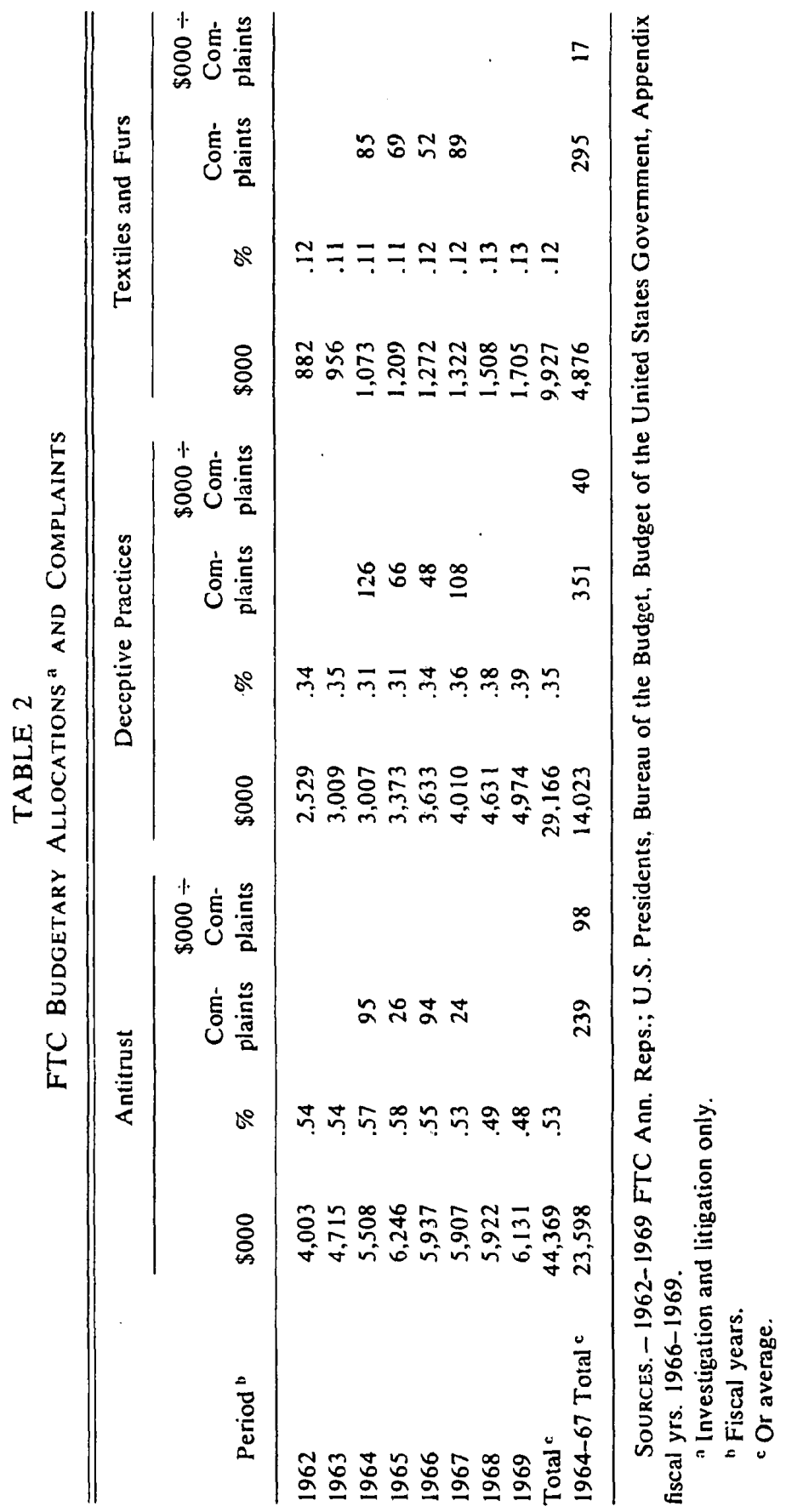


TABLE 3

Dismissal Rate-Federal Trade Commission

(Contested Cases Only)

\begin{tabular}{lcccc}
\hline \hline Period & Total Cases & $\begin{array}{c}\text { Antitrust } \\
\text { Cases }{ }^{\text {a Only }}\end{array}$ & $\begin{array}{c}\text { Dismissed } \\
(\%)\end{array}$ & $\begin{array}{c}\text { Dismissed } \\
\text { Antitrust } \\
\text { Cases Only } \\
(\%)\end{array}$ \\
\hline 1938 & 60 & 4 & .12 & .25 \\
1941 & 61 & 15 & .28 & .60 \\
1943 & 32 & 6 & .22 & .53 \\
1945 & 43 & 6 & .21 & .33 \\
$1946-47$ & 70 & 7 & .21 & .43 \\
$1949-50$ & 53 & 10 & .17 & .40 \\
$1951-52$ & 62 & 3 & .19 & .33 \\
$1955-56$ & 36 & 12 & .19 & .25 \\
$1959-60$ & 58 & 7 & .12 & .29 \\
1965 & 34 & 15 & .29 & .60 \\
Total c & 509 & 85 & .20 & .44 \\
\hline
\end{tabular}

Sources. - Federal Trade Commission Decisions, vols. 27, 33, 37, 40, 42$43,46,48,52,56,67-68$.

a Excluding cases brought exclusively under one of the minor Robinson-Patman amendments to the Clayton Act. See note 10, supra.

${ }^{\text {b }}$ Significant total dismissals, as defined in text, infra, p. 240.

c Or average.

average is in fact much lower; and the higher dismissal rate is found in the class of larger cases.

Results from a single agency can hardly be considered conclusive; and the classification of cases employed in Tables 2 and 3 is crude. The tests can, however, be refined, and extended to other agencies.

The question arises whether alternative models of the administrative process might not explain the evidence equally well. I believe not. The model implicit in the standard criticism mentioned earlier (agencies spend too much money on small cases) is that administrative agencies are not competent utility maximizers. In that event, however, one would expect the agency either to dismiss a high proportion of cases or suffer reversal at the hands of reviewing courts in a high proportion of cases. In fact the FTC fares extremely well on judicial review. ${ }^{12}$

12. See Table 16, infra. 
Another model characterizes the administrative agencies as tools of effective political groups. ${ }^{13}$ An implication of this model that I have discussed elsewhere is that the FTC can be expected to bring a large number of questionable cases to harass the competitors of the firms or groups of firms that dominate the agency. ${ }^{14}$ Such cases would rather often end in dismissal, either by the agency in anticipation of adverse court action or by a reviewing court. We would therefore expect - but we do not observe -a high dismissal or reversal rate.

\section{The Model Made More Realistic}

In this subpart, several severely unrealistic assumptions made in subpart $A$ are progressively relaxed, and we ask what difference relaxing them makes to the predictions derived from the original model.

\section{NUMBER OF CASES AS AN ADDITIONAL CHOICE VARIABLE}

We assumed that the number of cases of each type brought by the agency was fixed, but in fact the agency, within the limits of its budget, can bring as many or as few of each type of case as it wants. Once we admit $n$ as a choice variable along with $c$, we must further modify our original model to take account of the fact that the probability of an agency's winning its $n$th case will decline as $n$ increases, other things being equal. Within any size class of cases, there will be some violations that can be detected and proved with relative ease and others that require much more investigative and litigative effort. Thus, the more cases in the class that the agency decides to bring, the more it will be forced to seek out cases that are more difficult to win with the same expenditure of resources. ${ }^{15}$ Figure 1 illustrates this relationship. The area under the curve to the left of the broken line is the cumulative probability (as estimated by the agency) of winning $n_{1}$ cases, given equal expenditures per case. If this area is multiplied by $s_{1}$, the product is the agency's expected utility from bringing $n_{1}$ cases. If it brings more cases its expected utility will increase but at a declining rate.

13. See George J. Stigler, The Theory of Economic Regulation, 2 Bell J. Econ. \& Management Sci. 3 (1971).

14. See Richard A. Posner, The Federal Trade Commission, supra note 10, at 70-71.

15. The negative slope of $p(n)$ is reinforced by two other factors. First, the more cases of a given type an agency brings, the larger will be the body of applicable precedents and this will tend to reduce uncertainty and so increase the proportion of cases that are settled (the determinants of settlement are discussed in detail later): contested cases will be scarcer. Second, bringing more cases is likely to increase the deterrent effect of the law. With the risk of being prosecuted greater, fewer violations will be committed and this will make it more difficult for the agency to find additional violations against which to proceed. 


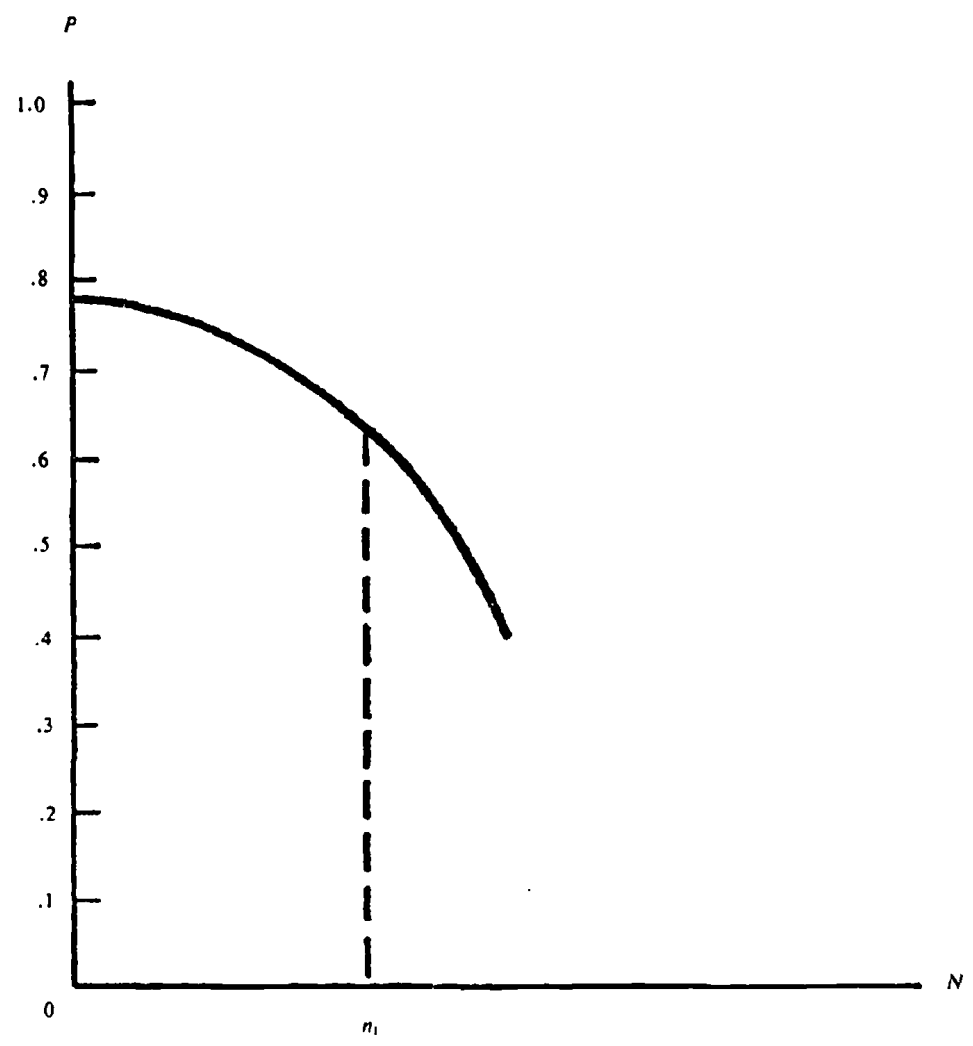

Figure 1

These new assumptions could be incorporated into a revised algebraic formulation of the agency's utility function, but such a formulation turns out to be quite awkward to manipulate. For our purposes a graphic approach (Figure 2) is sufficient. Dollars, on the vertical axis, are plotted against number of cases on the horizontal axis. Cases of type 1 are to the left of the vertical axis and cases of type 2 to the right. Assume a new agency, groping its way to the optimum combination of $c$ 's and $n$ 's by a process of trial and error. It begins by selecting a point somewhere to the right of the vertical axis (it could just as well, however, have begun on the left side). That point $\left(c_{2} n_{2}\right)$ determines both the number of cases of type 2 that the agency will bring and the expenditure it will make on each such case. ${ }^{16}$ The choice of that point also constrains the selection of a

16. The assumption that the agency will spend the same amount of money on cases having different probabilities of success is somewhat arbitrary. Assume that the probability of the agency's winning the first case is .9 and of winning the $n$th case .6 , and that an addi- 


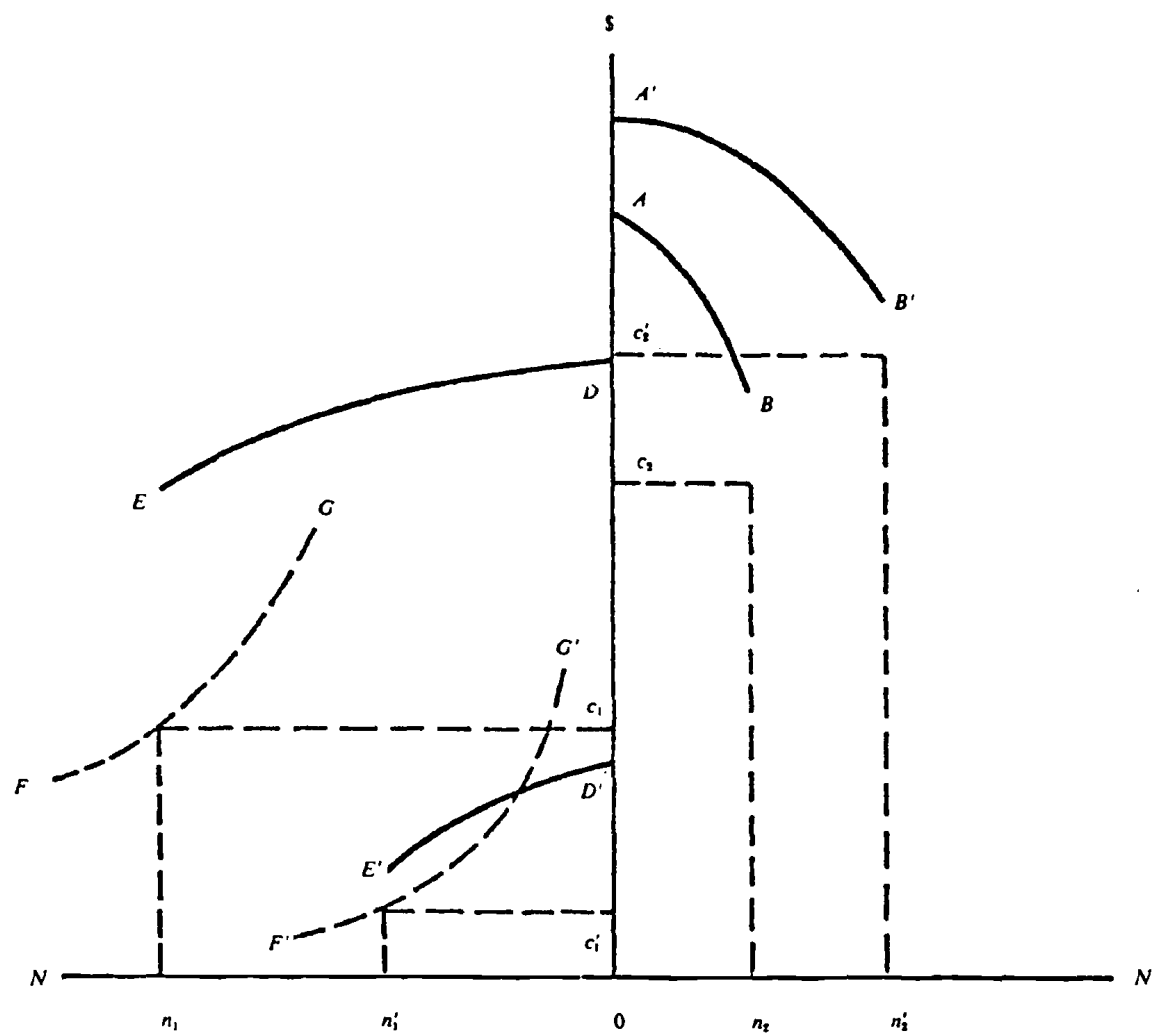

FIGURE 2

point on the left side of the diagram, since $B$ is given and $c_{1} n_{1}=B-$ $c_{2} n_{2}$.

To every point on either side of the vertical axis, there corresponds a unique function, of the kind depicted in Figure 1 but now multiplied by $s$, that determines the expected utility of bringing a particular number of cases and spending a particular amount of money on each one. The expected-utility function for $c_{2} n_{2}$ in the diagram is the curve $A B$. The area

tional expenditure of $\$ 1$ per case would increase these probabilities by .1 . Assuming constant $s$, the $\$ 1$ increment will produce a larger gain in expected utility in the first case than in the second $(.1 \times .9 s$, or $.09 s$, compared to $.1 \times .6 s$, or $.06 s)$. This would seem to suggest that the agency would be better off spending more of the increment on the first case and less on the $n$ th. However, an additional expenditure on a case in which the agency's chances of winning are already high may increase those chances less than the same expenditure would increase the agency's chances in a case where those chances would otherwise be poor. At all events, Figure 2 could be modified to give the c's a negative slope, and the analysis would not be affected. 
between that curve and the baseline is the expected utility of bringing $n_{2}$ cases and spending $c_{2}$ on each one. Notice that while the curve must lie in the same vertical plane as $c_{2} n_{2}$, it need not, and ordinarily will not, touch $c_{2} n_{2}$. There is no presumption that the expenditure on the $n$th case is equal to the expected utility of bringing that case. It may be lower; assuming a tight budget constraint, it may very well be higher (as in the diagram).

The curve $F G$ on the left side of the diagram represents the locus of points $c_{1} n_{1}$ equal to $B-c_{2} n_{2}$, the sum of the rectilinear areas $c_{1} n_{1}$ and $c_{2} n_{2}$ being the constant $B$. To every point on that curve there again corresponds some unique expected-utility function. We assume the agency selects the $c_{1} n_{1}$ shown in the diagram, with its corresponding utility function $D E$.

It is no accident that in the diagram $c_{1}$ is below $c_{2}$ and $D E$ both below and flatter than $A B$. Recall that type 2 comprises the larger cases and type 1 the smaller. Since $c$ is an increasing function of $s, c_{2}$ will usually (not always) be larger than $c_{1}$ when $s_{2}>s_{1}$. Since the expected-utility functions are the product of $s$ times $p, A$ may well be higher than $E$ even if $p_{1}$ is greater than $p_{2}$. The only nonobvious assumption is that $D E$ is flatter than $A B$, signifying that the probability of the agency's winning declines more slowly, as more cases are brought, in the class of smaller than in the class of larger cases. This is plausible. It implies that the universe of major violations is smaller than the universe of minor ones. The ratio of all transactions that can plausibly be characterized as monopolization in violation of the antitrust laws to those such transactions against which proceedings are instituted is doubtless much smaller than the comparable ratio for consumer frauds. If so, bringing an additional monopolization case (and spending no more money on it than was spent on the last such case) probably involves a larger drop in the probability of a successful outcome for the agency than would bringing an additional fraud case.

Figure 2 illustrates how, on these assumptions, the agency that takes a critic's advice to "reorder its priorities" by bringing more big cases and spending more money on each one may actually reduce its overall effectiveness. By moving to $c_{2}^{\prime} n_{2}^{\prime}{ }^{17}$ the agency increases its expected utility from bringing cases of type 2 to the area under the curve $A^{\prime} B^{\prime}$, but this reduces the resources it can devote to cases of type 1 to the locus of points on $F^{\prime} G^{\prime}$. Suppose $c_{1}^{\prime} n_{1}^{\prime}$ is the point that generates the largest expected utility (the area under the curve $D^{\prime} E^{\prime}$ ). Partly because the expected-utility functions for cases of class 1 are flatter than those for cases of class 2 the result of this reallocation of resources is to reduce

17. The prime marks here do not refer to defendants' expenditures. 
the total expected utility of the agency (the area under $E^{\prime} D^{\prime} A^{\prime} B^{\prime}$ is smaller than the area under $E D A B$ ).

Relaxing the assumption that the number of cases of each type brought by the agency is fixed thus reinforces rather than undermines the implications of the primitive model. The analysis that underlies Figure 2 not only suggests why (as we have observed) the FTC brings many more small cases than large but also why it seems to devote excessive resources to small cases in the aggregate.

\section{BUDGET AS AN ENDOGENOUS TERM}

So far we have assumed that the agency's budget, or overall resources, is an exogenous variable, meaning that it is not affected by changes in the variables that the agency controls, the $c$ 's and $n$ 's. There is some evidence that administrative agency budgets do in fact contain a large exogenous element, ${ }^{18}$ but they cannot be wholly exogenous. The agency that brought no cases or lost every case it brought would surely suffer a reduction in its budget.

To illustrate the consequences of abandoning the assumption that $B$ is exogenous, let us assume that it tends to rise as the agency's work load rises (as discussed more fully later, discussion of work load in fact dominates congressional hearings on appropriations for administrative agencies) but to fall if the agency's batting average $(\dot{p})$ falls (otherwise an agency that wanted a larger budget would bring cases without regard to their merit). The agency and the appropriating body are also interested, presumably, in $s$, but this does not affect the analysis.

This model has the same implications as Figure 2. As in Figure 2, the agency has an incentive to increase $n$ but this incentive is held in check by the negative impact on $p$ of a higher $n$ if the slope of $p(n)$ is steep. Thus, that slope, which I have suggested provides additional reason for expecting an agency to concentrate major resources on small cases, remains a vital element in the agency's utility function.

\section{SETTLEMENTS}

Our original model excluded the possibility of a settlement without trial. Not only is this unrealistic, but it invites the objection that the predictions of the primitive model may be incorrect. If, for example, large cases are

18. This is strikingly shown in a study by George $\mathbf{J}$. Stigler, who found that changes in agency budgets are much more closely correlated with each other than with differences in the size or rate of growth of the respective industries regulated. George J. Stigler, The Process of Economic Regulation, 17 Antitrust Bull. 207, 218 (1972). 
more apt to be settled than small, this would imply that the former are relatively cheap to prosecute, and a rational utility-maximizing agency will therefore allocate greater resources to large cases than the primitive model predicted. We must consider the conditions under which a case will be tried rather than settled.

The minimum offer that a rational plaintiff will accept in settlement of his claim is his expected gain from litigation minus his litigation expenses (which would reduce his net gain from suit) plus the costs of negotiating the settlement. The maximum offer that the defendant will tender is what he expects to owe the plaintiff after the litigation (the stakes to the defendant discounted by the probability, in the defendant's eyes, of the plaintiff's winning) plus his litigation expenses (which he would lose anyway) minus his settlement costs. For a settlement to take place, the plaintiff's minimum settlement price must not exceed the maximum that the defendant is willing to pay. If it is larger there will be no settlement. I assume that settlement cost is some fraction of each party's litigation costs - the same fraction.

The condition for litigation may therefore be expressed as follows:

$$
\frac{c e s}{c+c^{\prime}}-c+\frac{c}{k}>s^{\prime}\left(1-\frac{e^{\prime} c^{\prime}}{c^{\prime}+c}\right)+c^{\prime}-\frac{c^{\prime}}{k},
$$

which simplified (with the help of equation (8)) becomes

$$
e>\frac{s^{\prime}}{s}\left[\sqrt{\frac{e^{\prime} s^{\prime}}{c}}\left(1-e^{\prime}\right)+e^{\prime}\left(2-\frac{1}{k}\right)\right] \text {. }
$$

The larger the ratio of $s^{\prime}$ to $s$ the likelier a settlement. (The intuitive explanation is that the prospect of a large loss induces the defendant to make an offer that the agency, with the prospect of a relatively small gain from litigation, finds attractive.) And for reasons explained earlier that ratio may be larger in big cases than in small. Notice, however, that when $e^{\prime}>1$, the same percentage increase in $s$ and $s^{\prime}$ will reduce the likelihood of settlement by making the first term in brackets a larger negative number.

An increase in settlement costs relative to litigation costs (falling $k$ ) reduces the right-hand side of inequality (15): litigation becomes more likely. ${ }^{19}$ An increase in $e^{\prime}$ (the effectiveness of the defendant's litigation outlays) produces a more complex effect, but in general the decline in the first term in brackets will exceed the rise in the second term. However, it is unrealistic to assume that if $e^{\prime}$ rises $e$ will remain unchanged, for

19. For some evidence of this effect see Richard A. Posner, supra note 6, at 94-96. 
whatever causes the defendant to revise his chances upward should cause the agency to revise its chances downward. We can investigate this possibility by assuming that the sum of the parties' estimates of their chances of prevailing is a constant $\left((e c) /\left(c+c^{\prime}\right)+\left(e^{\prime} c^{\prime}\right) /\left(c+c^{\prime}\right)=r\right)$, so that any increase in $e^{\prime}$ must be offset by a decrease in $e$. As shown in the appendix at the end of this article, in the special case where $r=1, k>1$ (settlement costs are lower than litigation costs), and $s^{\prime}=s$, there will always be a settlement, whether $e^{\prime}$ rises or falls. Intuitively, when the parties' estimates sum to 100 per cent, it means that they agree on the outcome, so a settlement can readily be negotiated. ${ }^{20}$

The more interesting case is where $r>1$. Assuming that $k$ is large and $s^{\prime}=s$, the condition for litigation is (approximately)

$$
\sqrt{e^{\prime}}<\sqrt{\frac{s}{c}}(r-1)
$$

This would seem to indicate that litigation becomes more likely as $e^{\prime}$ decreases and less likely as it increases. But this is misleading. A decrease in $e^{\prime}$ and increase in $e$ will produce an increase in $c$ (equation (11)): thus the right-hand side of the inequality will also decrease. What is clear is that an increase in $r$, which measures the divergence of the parties' predictions of success, will increase the likelihood of litigation. An increase in the stakes $(s)$ will also increase the likelihood of litigation - a prediction that has some empirical support. ${ }^{21}$

Thus far we have assumed that the effectiveness of a dollar expended in litigation $(e)$ is a constant that is unaffected by the number of dollars expended, which is unrealistic. In particular, there is probably a threshold below which expenditures on litigation have no, or negligible, effectiveness. If the defendant's threshold expenditure is larger than his stakes in the case, he will not contest the agency's case and the case will be classified as a settlement. To be sure, assuming that the agency has the same threshold, it will not be able to make a credible threat of suing in order to induce the defendant not to contest unless the agency's stakes (unlike the defendant's) exceed the threshold. But since $s$ may be larger than $s^{\prime}$,

20. Assuming (as incidentally I do throughout the paper) that neither party is a risk preferrer. The relevance of attitude toward risk to the likelihood of settlement is discussed in William M. Landes, p. 171.

21. The FTC settles small cases more frequently than large. (Compare Tables 3 supra and 12 infra with Table A3 in the appendix.) But this could be because the outcome of antitrust cases-the large cases, in our statistics-is less predictable than that of deceptive-practices cases (the small cases in our statistics): the $r$ may be greater. 
there will be cases where this condition is fulfilled. These will be small cases, since the threshold litigation expenditure must exceed $s^{\prime}$. Here is then another reason for expecting settlements to include a disproportionately large number of small cases, consistently with the predictions of the primitive model.

If we solve inequality (15), using the values in our earlier numerical example and assigning a value of 5 to $k$ (signifying that the costs of settlement are one-fifth of the costs of trial) we find that type 1 cases will not be settled. This is not because the parties have different stakes $\left(s_{1}\right.$ and $s_{1}^{\prime}$ are the same) but because they disagree sharply about the outcome. The agency estimates the probability of its winning at 87 per cent, while defendants estimate the agency's probability of winning at only 51 per cent. In cases of the second type, where the spread is smaller (the agency estimates its probability of winning at 43 per cent and the defendant estimates the agency's probability of winning at 28 per cent) the parties do settle. Although arbitrary, the numerical example suggests roughly how great a difference there must be between the parties' estimates of probability, given moderate settlement costs and equal stakes, for litigation to occur. Additional examples (again with $k=5$ ) are presented in Table 4.

In the numerical example, the larger difference in the parties' estimates of their chances of success was in the smaller case but this is an accident of the numbers. On the one hand, prediction is more difficult the more complex a case is, and complexity is in part a function of size (though even more of novelty). On the other hand, the greater legal resources deployed in the larger case may result in narrowing the area of uncertainty about the outcome.

Our discussion of settlements assumes that the parties cooperate to maximize their joint utility. Our discussion of litigation assumed that

TABLE 4

Settled vs. Litigated Cases

\begin{tabular}{lcccccc}
\hline \hline & $\begin{array}{c}\text { Hypo- } \\
\text { thetical 1 }\end{array}$ & $\begin{array}{c}\text { Hypo- } \\
\text { thetical 2 }\end{array}$ & $\begin{array}{c}\text { Hypo- } \\
\text { thetical 3 }\end{array}$ & $\begin{array}{c}\text { Hypo- } \\
\text { thetical 4 }\end{array}$ & $\begin{array}{c}\text { Hypo- } \\
\text { thetical 5 }\end{array}$ & $\begin{array}{c}\text { Hypo- } \\
\text { thetical 6 }\end{array}$ \\
\hline $\begin{array}{c}\text { Case } \\
\text { type 1 }\end{array}$ & $\mathrm{S}$ & $\mathrm{S}$ & $\mathrm{L}$ & $\mathrm{L}$ & $\mathrm{L}$ & $\mathrm{L}$ \\
$\begin{array}{c}\text { Case } \\
\text { type 2 }\end{array}$ & $\mathrm{S}$ & $\mathrm{S}$ & $\mathrm{S}$ & $\mathrm{S}$ & $\mathrm{L}$ & $\mathrm{S}$ \\
\hline
\end{tabular}

SOURCE. - Table 1. 
they make independent, noncooperating decisions on their litigation outlays, even though, by agreeing to reduce those outlays, both would be made better off. The dichotomy corresponds at least to casual observation of the operation of the legal system. In a very large class of cases the parties agree to settle in advance of trial and thereby avoid all costs of trial. In cases that are tried, the parties frequently do stipulate to many of the facts essential to the proceeding in order to avoid the costs of having to establish the facts by testimony in court, but such side agreements appear to be less common than settlements and to avoid a smaller proportion of the total costs of going to law. Possibly the transaction costs involved in agreements to curtail the trial process are relatively high, especially since the cases that are not settled - a minority of all cases - are by definition those in which an effort at a meeting of the minds failed. In general, then, a model of cooperative decision making seems more appropriate in the settlement context, and a model of independent decision making more appropriate in the litigation context.

\section{DOES COMBINING PROSECUTION AND ADJUDICATION IN THE SAME AGENCY CONTAMINATE ADJUDICATION?}

\section{A. The Elman Thesis}

An old debate in administrative law-over whether the combination of prosecution and adjudication in a single agency contaminates adjudication ${ }^{22}$ - has recently been revived by Philip Elman, a distinguished former member of the Federal Trade Commission. In a recent article, he points to several specific characteristics of an administrative agency that make the combination of these functions likely, in his judgment, to create unfairness:

1. A high rate of dismissals is a confession of ineptitude on the part of the members of the agency, who authorized the bringing of the cases in the first place.

2. It is a rebuff to the staff that investigated and prosecuted the case

22. I use "combination of functions" to mean that an agency initiates the cases that it decides, not that members of the Commission participate in the actual prosecution or that members of the prosecutorial staff participate (other than through briefs and oral argument) in the decision. The latter forms of combination have long been considered highly improper, and to my knowledge have never characterized the agencies I shall be discussing. 
on the agency's behalf - a staff on which the members of the agency depend.

3. It encourages noncompliance with the statute that they are committed to enforcing. ${ }^{23}$

Although plausible, this reasoning is hardly compelling. It can equally well be argued that an agency will be motivated to review contested cases scrupulously in order to keep the staff on its toes and minimize the likelihood of reversal by a reviewing court. Furthermore, if it is true that an agency measures its success by the number of cease and desist orders entered, it will refuse to dismiss complaints regardless of whether it, its delegate, or a complete outsider brought the case initially.

Nor can we resolve doubt in favor of Professor Elman's position on the ground that it is implicitly based on his extensive personal observation as a member of the Trade Commission. What he observed is that Commission members frequently lack the fair-mindedness expected of judges; and this bears hardly at all on the issue under discussion. Are Federal Trade Commissioners more biased than the average judge? Would they be less biased if they sat on a court rather than on the Commission or if their authority over the issuance of complaints were removed?

\section{B. Testable Implications of the Elman Thesis}

The Elman thesis has several testable implications:

1. An agency in which prosecution and adjudication are separated will dismiss a higher fraction of the cases it decides than one in which these functions are united, other things being equal.

2. When an agency in which these functions are combined does dismiss a complaint, it will tend to do so in a manner that avoids an acknowledgment that the agency erred in initially authorizing the complaint.

3. Such an agency will be more reluctant to dismiss a case in which the issues are primarily factual than one in which the issues are primarily legal.

4. It will be more reluctant to dismiss a big case-big in terms of the amount of agency resources invested in it - than a small one.

5. It will be more reluctant to dismiss a complaint that the current

23. See Philip Elman, supra note 9, at 810 . To similar effect see Richard A. Posner, The Federal Trade Commission, supra note 10, at 53. 
members of the agency authorized than one authorized by their predecessors.

6. The decrees of an agency in which the functions arc combined will be reversed more frequently on judicial review than those of an agency in which the functions are separated.

7. In congressional hearings on an agency's appropriation requests, and in other scrutinies of the agency's performance, the agency's dismissal rate will receive greater emphasis than its rate of reversal on judicial review if prosecution and adjudication are combined in the agency.

These hypotheses can be explored using data from the major federal administrative agencies concerned primarily with the prosecution of law violators - the Federal Trade Commission and the National Labor Relations Board. The Commission has never relaxed its authority over the issuance of complaints. The Labor Board's authority, in contrast, has progressively diminished. ${ }^{24}$ Prior to October 1942 all complaints had to be formally approved by the Board. Beginning with that date the Board's Regional Directors were authorized to issue complaints without first notifying the Board or obtaining its approval, unless a novel question of fact or law was presented, and in the first year of operation under the new system 70 per cent of all complaints were issued without a reference to the Board. ${ }^{25}$ The Taft-Hartley Act in 1947 carried separation one step further by making the General Counsel of the Board a presidential appointee rather than an employee of the Board and by giving him exclusive authority over the issuance of complaints. ${ }^{26}$ This sequence affords interesting opportunities for comparison among different periods of the Labor Board as well as between Board and Commission.

\section{The Empirical Evidence}

1. Elman implies that any bias created by the combination of prosecution and adjudication will show up in a reduced dismissal rate. Our original model supports this view. Substituting equation (8) (defendant's optimum litigation outlay) into equation (13) (the true probability of the agency's winning), and rearranging some terms, we have

24. See U.S. Atty. Gen.'s Committee on Administrative. Procedure, Administrative Procedure in Government Agencies, S. Doc. No. 8, 77th Cong., 1st Sess. 22-23 (1941); 3 NLRB Ann. Rep. 5 (1938); Ida Klaus, The Taft-Hartley Experiment in Separation of NLRB Functions, 11 Indus. \& Lab. Rel. Rev. 371, 372-74 (1958).

25. See 7 NLRB Ann. Rep. 12, n.5 (1942); 8 NLRB Ann. Rep. 13 (1943).

26. See $\S 2$ (d) of the National Labor Relations Act, 29 U.S.C. $\S 153$ (d) (1970). 


$$
\dot{p}=\frac{\sqrt{c}}{2 \sqrt{s^{\prime}}}\left(\frac{e+e^{\prime}}{\sqrt{e^{\prime}}}\right)+\frac{1-e^{\prime}}{2} .
$$

The effect of introducing bias in the agency's favor is to increase $e$ and decrease $e^{\prime}$, making both terms on the right-hand side of the equation larger.

In the more complex model illustrated in Figure 2, the effect on the dismissal rate of an increase in $e$ and a corresponding decrease in $e^{\prime}$ is not so easy to predict. Typically the immediate consequence will be to shift all of the expected-utility functions upward. If each increases equally and $c_{1} n_{1}$ and $c_{2} n_{2}$ were optimum points before the shift, the agency has no reason to move to different points and $p_{1}$ and $p_{2}$ (and therefore $\dot{p}_{1}$ and $\dot{p}_{2}$ ) will increase (the dismissal rate will fall). But a change in $e$ and $e^{\prime}$ could well affect different utility functions differently. In that event the agency might alter its $c n$ points and the new points might involve a larger $n$ and a lower probability of success in the $n$th case than before the shift. Still, an increase in $e$ accompanied by a decrease in $e^{\prime}$ will ordinarily reduce the agency's dismissal rate, for the increase in the agency's overall dismissal rate due to bringing some additional cases is unlikely to equal or exceed the decrease in that rate due to a higher $e$ and lower $e^{\prime}$ in all of its cases.

One effect of a declining $e^{\prime}$ that we do not predict is a change in the settlement rate. Any bias introduced by combination of functions would presumably be perceived by both parties roughly equally: the $r$ of inequality (16) would not change.

Table 5 presents dismissal rates for more than 1,100 NLRB unfair labor practice cases and FTC cases, drawn from randomly selected volumes of the agencies' official decisions for various periods since $1938 .{ }^{27}$ It reveals that the Commission's dismissal rate has in general been a good deal higher than the Board's both before and after 1947, while the Board's has artually decreased since the creation of the independent General Counsel. Little significance, however, can be ascribed to these

27. Decisions are published in these volumes in the chronological order in which they were issued. While a volume of NLRB decisions ordinarily covers no more than two months, an FTC volume will usually cover an entire year's decisions. My procedure was first to select volumes of NLRB decisions at random from various periods, concentrating on the years immediately before and immediately after a change in the Board's structure with respect to separation of functions, and then to select the contemporaneous FTC volume. I omitted the very early years of the Board's decisions on the ground that its early experience might be unrepresentative; however, some evidence on the earliest period is presented in Tables 8 and 11 and note 34, infra. I omitted 1969 in the case of the FTC because its decisions for that year had not yet appeared in a printed volume and because it decided very few cases that year. 
TABLE 5

DISMISSAL RATE

\begin{tabular}{|c|c|c|c|c|c|c|c|}
\hline Agency & Period & $\begin{array}{l}\text { Total } \\
\text { Cases } \\
\text { Con- } \\
\text { tested }\end{array}$ & $\begin{array}{l}\text { Cease } \\
\text { and } \\
\text { Desist } \\
\text { Order } \\
\text { Entered }\end{array}$ & $\begin{array}{l}\text { Com- } \\
\text { plaint } \\
\text { Dis- } \\
\text { missed } \\
\text { in Part } \\
\text { or Whole }\end{array}$ & $\begin{array}{l}\text { Com- } \\
\text { plaint } \\
\text { Dis- } \\
\text { missed } \\
\text { in Its } \\
\text { Entirety }\end{array}$ & $\begin{array}{c}\% \\
\text { Dis- } \\
\text { missed } \\
\text { in Part } \\
\text { or } \\
\text { Whole }\end{array}$ & $\begin{array}{c}\% \\
\text { Dis- } \\
\text { missed } \\
\text { in } \\
\text { Whole }\end{array}$ \\
\hline \multirow[t]{7}{*}{ NLRB } & 1938 & 33 & 28 & 25 & 5 & .76 & .15 \\
\hline & 1941 & 18 & 17 & 8 & 1 & .44 & .06 \\
\hline & 1943 & 26 & 20 & 16 & 6 & .62 & .23 \\
\hline & 1945 & 16 & 12 & 7 & 4 & .44 & .25 \\
\hline & 1946 & 27 & 21 & 15 & 6 & .56 & .22 \\
\hline & 1947 & 20 & 15 & 11 & 5 & .55 & .25 \\
\hline & Total a & $\overline{140}$ & $\overline{113}$ & $\overline{82}$ & $\overline{27}$ & $\overline{.59}$ & .19 \\
\hline \multirow[t]{6}{*}{ FTC } & 1938 & 60 & 43 & 26 & 16 & .43 & .27 \\
\hline & 1941 & 61 & 39 & 31 & 22 & .51 & .36 \\
\hline & 1943 & 32 & 19 & 14 & 13 & .44 & .41 \\
\hline & 1945 & 43 & 26 & 23 & 17 & .53 & .40 \\
\hline & $1946-47$ & 70 & 21 & 56 & 49 & .80 & .70 \\
\hline & Total " & $\overline{266}$ & $\overline{148}$ & $\overline{150}$ & $\overline{117}$ &.$\overline{56}$ & $\overrightarrow{.44}$ \\
\hline \multirow[t]{8}{*}{ NLRB } & 1949 & 38 & 27 & 30 & 11 & .79 & .29 \\
\hline & 1950 & 52 & 43 & 24 & y & .46 & .17 \\
\hline & 1951 & 57 & 48 & 33 & 9 & .58 & .16 \\
\hline & 1956 & 57 & 48 & 35 & 9 & .61 & .16 \\
\hline & 1960 & 105 & 83 & 55 & 22 & .52 & .21 \\
\hline & 1965 & 103 & 90 & 28 & 13 & .27 & .13 \\
\hline & 1969 & 70 & 54 & 35 & 16 & .50 & .23 \\
\hline & Total $^{\mathrm{a}}$ & $\overline{482}$ & $\overline{393}$ & $\overline{240}$ & $\overline{89}$ & $\overline{.50}$ & .18 \\
\hline \multirow{6}{*}{ FTC $^{\mathrm{b}}$} & $1949-50$ & 53 & 24 & 38 & 29 & .72 & .55 \\
\hline & $1951-52$ & 62 & 41 & 37 & 21 & .60 & .34 \\
\hline & $1955-56$ & 36 & 28 & 13 & 8 & .36 & .22 \\
\hline & $1959-60$ & 58 & 39 & 36 & 19 & .62 & .33 \\
\hline & 1965 & 34 & 19 & 18 & 15 & .53 & .44 \\
\hline & Total ${ }^{a}$ & $\overline{243}$ & $\overline{151}$ & $\overline{141}$ & 92 & .58 & .38 \\
\hline
\end{tabular}

SourCEs. - Decisions and Orders of the National Labor Relations Board, vols. 8, 35 , $51,60,69,72,87,91,95,115,127,153,178$; Federal Trade Commission Decisions, vols. $27,33,37,40,42-43,46,48,52,56,67-68$.

a Or average.

Dxclusion of 1969 FTC cases, in this and subsequent tables, is explained in note 27, supra. 
findings. Table 1 counts as a dismissal any case in which, and for whatever reason, any part of the complaint was dismissed. ${ }^{28}$ Many are unimportant partial dismissals. And complaints are frequently dismissed in circumstances where the outcome seems better characterized as a victory for the agency than as a victory for the defendant, such as where the defendant has discontinued the unlawful practice in circumstances where resumption seems highly unlikely.

Table 6 organizes the dismissal data in a more discriminating manner. Dismissals that, for the reasons just stated, are not really significant are excluded. According to Table 6 the NLRB's dismissal rate is approximately the same in the period before and in the period after 1947. If partial dismissals are included the FTC's dismissal rate is lower than the Board's in both periods. If partial dismissals are excluded the Commission's dismissal rate is very slightly higher than the Board's in both periods.

Although the relative dismissal rates of the Labor Board and the Trade Commission do not support the Elman position, neither do they refute it, since $\dot{p}$ (and hence $1-\dot{p}$, the dismissal rate) is, as we know from our model, influenced by variables whose values cannot be assumed to be the same in two so dissimilar agencies as the Labor Board and the Trade Commission. ${ }^{29}$ But even if they cannot be used for direct comparison of the agencies, Tables 5 and 6 illuminate our question in two respects.

First, a good deal of the sense that administrative adjudication is biased against defendants may stem from a reaction to the low dismissal rates that characterize administrative adjudication. Instinctively we may think that in a "fair" system of adjudication the dismissal rate would tend toward 50 per cent. Our model of the behavior of administrative agencies shows, however, that a perfectly fair agency might nonetheless dismiss far fewer than 50 per cent of its cases. Tables 5 and 6 reinforce the impression that this is a general feature of administrative adjudication, rather than a distinctive attribute of agencies that have specific sources of contamination such as combination of functions.

28. A case in which there was a partial dismissal is counted twice-once in the order column and once in the dismissal column.

29. For this reason I have relegated to the appendix at the end of this article a table that compares the dismissal rate in contested cases brought by the Antitrust Division of the Department of Justice and in contested antitrust cases brought by the FTC-the area of overlap between the jurisdictions of the two agencies. Table Al shows, for what it is worth, that an antitrust defendant is as likely to convince the Commission to dismiss the complaint against him as he is to convince a court to dismiss a similar complaint brought by the Department, although the functions of prosecution and adjudication are completely separate in antitrust litigation initiated by the Department. 
TABLE 6

Dismissal Rate-Significant a Dismissals Only

\begin{tabular}{|c|c|c|c|c|c|c|}
\hline Agency & Period & $\begin{array}{l}\text { Total } \\
\text { Con- } \\
\text { tested } \\
\text { Cases }\end{array}$ & $\begin{array}{l}\text { Signifi- } \\
\text { cant } \\
\text { Dis- } \\
\text { missals }\end{array}$ & $\begin{array}{c}\text { Signifi- } \\
\text { cant } \\
\text { Total } \\
\text { Dis- } \\
\text { missals } \\
\text { Only }\end{array}$ & $\begin{array}{c}\% \\
\text { Dis- } \\
\text { missed }\end{array}$ & $\begin{array}{c}\% \\
\text { Dis- } \\
\text { missed } \\
\text { in En- } \\
\text { tirety }\end{array}$ \\
\hline \multirow[t]{7}{*}{ NLRB } & 1938 & 33 & 15 & 5 & .45 & .15 \\
\hline & 1941 & 18 & 4 & 1 & .22 & .06 \\
\hline & 1943 & 26 & 14 & 6 & .54 & .23 \\
\hline & 1945 & 16 & 5 & 4 & .31 & .25 \\
\hline & 1946 & 27 & 11 & 6 & .41 & .22 \\
\hline & 1947 & 20 & 10 & 5 & .50 & .25 \\
\hline & Total $^{\mathbf{b}}$ & $\overline{140}$ & $\overline{59}$ & $\overline{27}$ &.$\overline{.42}$ & $\overline{.19}$ \\
\hline \multirow[t]{6}{*}{ FTC } & 1938 & 60 & 12 & 7 & .20 & .12 \\
\hline & 1941 & 61 & 17 & 17 & .28 & .28 \\
\hline & 1943 & 32 & 8 & 7 & .25 & .22 \\
\hline & 1945 & 43 & 11 & 9 & .26 & .21 \\
\hline & $1946-47$ & 70 & 18 & 15 & .26 & .21 \\
\hline & Total $^{b}$ & $\overline{266}$ & $\overline{66}$ & $\overline{55}$ & .25 & .21 \\
\hline \multirow[t]{8}{*}{ NLRB } & 1949 & 38 & 26 & 11 & .68 & .29 \\
\hline & 1950 & 52 & 15 & 9 & .29 & .17 \\
\hline & 1951 & 57 & 26 & 9 & .46 & .16 \\
\hline & 1956 & 57 & 30 & 9 & .53 & .16 \\
\hline & 1960 & 105 & 48 & 22 & .46 & .21 \\
\hline & 1965 & 103 & 21 & 12 & .20 & .12 \\
\hline & 1969 & 70 & 29 & 16 & .41 & .23 \\
\hline & Total $^{\mathbf{b}}$ & $\overline{482}$ & $\overline{195}$ & $\overline{88}$ &.$\overline{.40}$ &.$\overline{.18}$ \\
\hline \multirow[t]{6}{*}{ FTC } & $1949-50$ & 53 & 11 & 9 & .21 & .17 \\
\hline & $1951-52$ & 62 & 15 & 12 & .24 & .19 \\
\hline & $1955-56$ & 36 & 10 & 7 & .28 & .19 \\
\hline & $1959-60$ & 58 & 21 & 7 & .36 & .12 \\
\hline & 1965 & 34 & 12 & 10 & .35 & .29 \\
\hline & Total ${ }^{b}$ & $\overline{243}$ & $\overline{69}$ & $\overline{45}$ & $\overline{.28}$ & $\overline{.19}$ \\
\hline
\end{tabular}

Sources. - See Table 5, supra.

a As defined in text.

b Or average. 
Second, it may be relevant that the disparity between dismissals and significant dismissals should be so much greater for the Commission than for the Board (indeed, virtually all total dismissals by the Board are significant in my sense of that term). The reason for the disparity is simply that it is not the Board's practice formally to dismiss a complaint when the defendant has discontinued the unlawful practice and resumption is unlikely - the usual ground of "nonsignificant" dismissal of a complaint in its entirety by the Commission. This procedural difference between the agencies is trivial but it is the opposite of what one would expect if Elman were correct, given that it is the Commission, not the Board, that issues as well as adjudicates complaints. Were the Commission highly sensitive to criticisms that dismissal of a complaint was an acknowledgment that the taxpayer's money had been wasted in bringing the case, it would seek wherever possible to avoid characterizing its action in closing a case as a dismissal. The Commission need not issue and print in its official decisions a formal order dismissing the complaint in every case where it finds entry of a formal order to cease and desist to be unnecessary.

Tables 5 and 6 allow a comparison among the several stages of the separation of functions at the Board. Table 7 summarizes the dismissal rates for each of the stages - before 1942, between 1943 and 1947, and since 1947.

The dismissal rate is higher in the two later periods, when prosecution and adjudication were separated, than in the first period, when they were not. This is consistent with Elman's thesis. The dismissal rate in the most recent period, that of formal separation, is lower than in the previous period, that of limited delegation to the Board's staff of authority to issue complaints; this is inconsistent with the thesis. The significance of

TABLE 7

Dismissal Rate-Significant a Dismissals (NLRB)

\begin{tabular}{lccccc}
\hline \hline Period & $\begin{array}{c}\text { Total } \\
\text { Contested } \\
\text { Cases }\end{array}$ & $\begin{array}{c}\text { Significant } \\
\text { Dismissals }\end{array}$ & $\begin{array}{c}\text { Significant } \\
\text { Total } \\
\text { Dismissals } \\
\text { Only }\end{array}$ & $\begin{array}{c}\% \\
\text { Dismissed }\end{array}$ & $\begin{array}{c}\% \\
\text { Dismissed } \\
\text { in Entirety }\end{array}$ \\
\hline $1938-41$ & 51 & 19 & 6 & .37 & .12 \\
$1943-47$ & 89 & 40 & 21 & .45 & .24 \\
$1949-69$ & 482 & 195 & 88 & .40 & .18 \\
\hline
\end{tabular}

Source. - Table 5, supra.

${ }^{a}$ As defined in text. 
these findings, however, is impaired by the limitations of our sample. The volumes of the official decisions of the Board from which it was drawn underrepresent the number of dismissals because they omit dismissals by hearing examiners that are not appealed to the Board. We can correct for this omission and also obtain complete statistics of the Board's actions rather than statistics based upon a sample by rearranging certain statistics in the Board's annual reports. ${ }^{30}$ Table 8 presents the results of these manipulations. Also, by being limited to unfair labor practices committed by employers, Table 8 corrects for the principal modifications in the law administered by the Labor Board that were made by the Taft-Hartley Act. $^{31}$

Table 8 overrepresents the number of contested orders entered against defendants by including cases in which the defendant filed exceptions to the trial examiner's recommended decision but did not file a brief - a course of action inconsistent with a serious effort to overturn the examiner's decision. (Such cases were omitted from the count of contested cases in the earlier tables.) At all events, there are marked disparities between the results in the previous tables and the results in Tabie 8. In particular, Table 8 indicates a substantial increase in the dismissal rate, however computed, after 1947. But this may not have been the result of separation of functions. The model developed in Part I of this

30. The FTC volumes, in contrast, record all dismissals; and a single volume covers a much longer period in the Commission's decisional process, thus reducing sampling error. All of the periods shown in Tables 5 and 6 of FTC decisions are a full 12 months, with the following exceptions: 1938 (seven months), 1941 (five months), 1943 and 1945 (six months each) and 1946-1947 (18 months).

31. Two related tables are printed in the appendix. Table A2 presents dismissals and withdrawals (often a charge is withdrawn because the Board's staff advises that it will not recommend a complaint) of charges, prior to formal issuance of a complaint, as percentages of total charges pending on the Board's docket. The table is relevant to the possible contention that a higher dismissal rate as a result of separating the prosecutorial and adjudicative functions might manifest itself at the precomplaint stage. Although Table A2 does reveal a rising precomplaint dismissal-withdrawal rate over time, the rate actually fell in the years immediately following the formal separation effected by the Taft-Hartley Act in 1947. A possible explanation for the secular rise in the rate - that a rising proportion of charges is being filed by individuals rather than unions and the proportion of meritorious claims is typically higher among union-initiated than among individually initiated charges - is explored with negative results in Table $A 2$.

Table A3 show's the FTC's dismissal rate as a percentage of all cases, and of all dispositions including informal settlements, to permit comparison with Table 8 -although, for reasons noted earlier, a direct comparison between the two agencies is extremely difficult. The caption "stipulations" in Table A3 refers to the only mode of informal settlement for which statistics are regularly reported. Stipulations were discontinued in the early 1960s. 


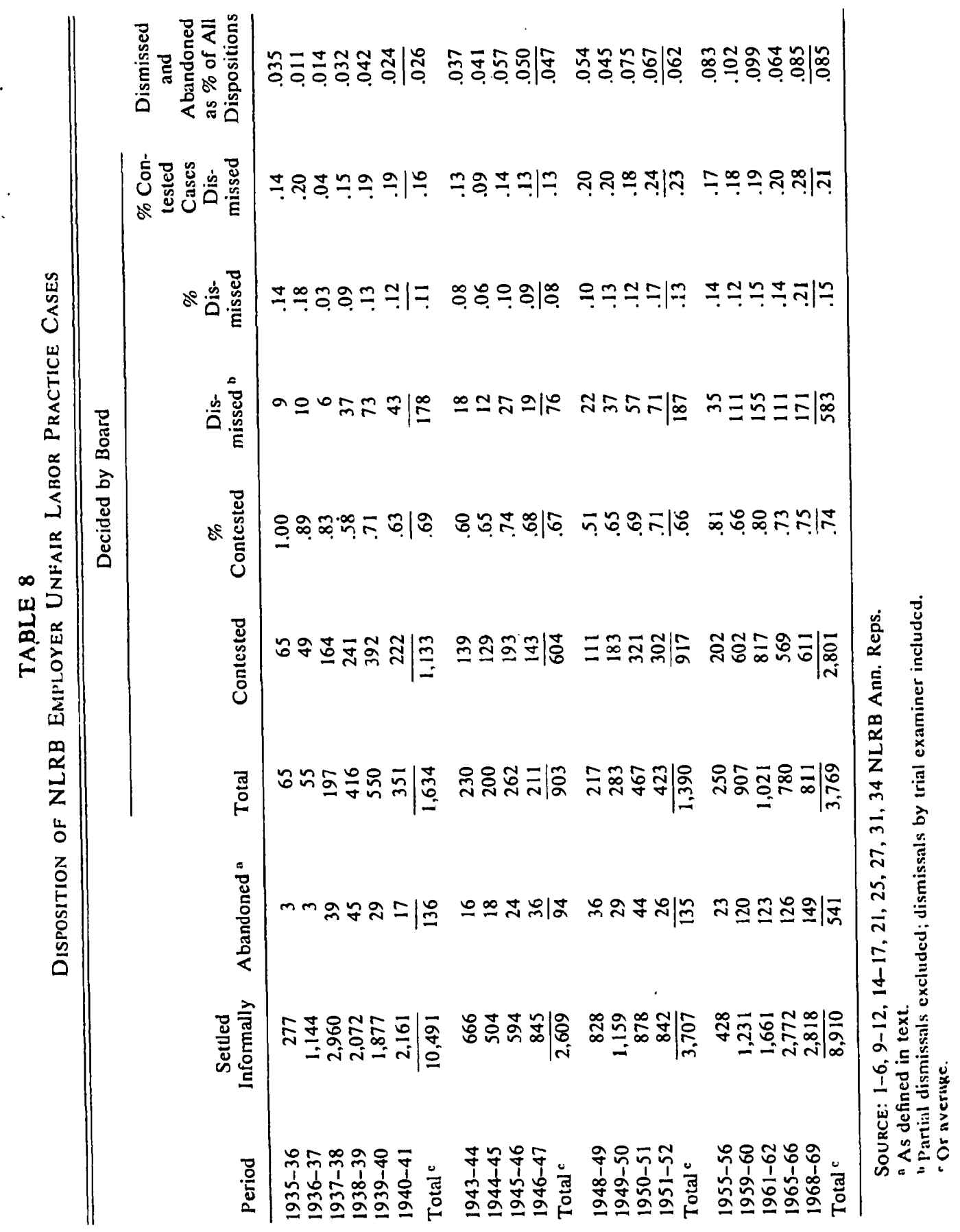


article predicts a positive correlation between agency resources and number of cases brought. A budget increase might produce an increase in dismissal rate if the change in the number of cases was large in relation to the resource change - if in other words the new resources went mostly to increasing $n$ rather than to increasing $c$ (and hence $\dot{p}$ ). This may be the explanation of the post-1947 increase in the dismissal rate.

A simple index of changes in the Board's resources during the four periods covered by Table 8 can be constructed by first distributing the Board's employees (by means of a simple weighting factor ${ }^{32}$ ) between its unfair labor practice business and its other business during the period, and then dividing the number of employees thus allocated to unfair labor practices enforcement in each period by the number of unfair labor practice charges lodged with the Board during that period. Table 9 translates the resulting quotients into an index in which the agency's resources in the first period, 1935-41, equals 100 .

Table 9 reveals that the agency's resources for dealing with unfair labor practices declined slightly in the period 1943-47 as compared with the prior period and that this decline was attended by a sharp drop in the number of contested cases and in the dismissal rate. In the next period the agency's resources increased, but the number of contested cases increased even more, and the dismissal rate rose. In the latest period, when both resources and the dismissal rate have fallen, the number of contested cases increases so markedly as to suggest a profound change either in the agency's productivity or in the character of its unfair labor practice cases.

According to Table 9, the Board actually expended fewer resources per case in the period 1948-52 than in the previous period - which, quite apart from the higher $n$, would lead us to predict an increase in the dismissal rate. Figure 3 shows how a reduction in $c$ combined with an even

32. The business of the Board consists primarily of two types of cases - unfair labor practice cases and representation cases. Representation cases apparently consume, on average, somewhere between 20 and 40 per cent of the agency resources required by the average unfair labor practice case. See Labor-Federal Security Appropriations Bill for 1948, Hearings before the Subcomm. of the S. Comm. on Appropriations, 80th Cong., 1st Sess. 866 (1947); Departments of Labor and Health, Education, and Welfare Appropriations for 1968, Hearings before a Subcomm. of the H. Comm. on Appropriations, 90th Cong., 1st Sess., pt. 1 at 835 (1967); Departments of Labor, and Health, Education, and Welfare Appropriations for Fiscal Year 1969, Hearings before the Subcomm. of the H. Comm. on Appropriations, 90th Cong., 2d Sess. 481 (1968). I equated representation to unfair labor practice cases at the rate of 3.5 representation cases to one unfair labor practice case. A problem was created by a third class of Board cases, union-authorization cases, which bulked large in the Board's activity in the third period covered by Table 8 . I used two exchange rates -3.5 and $4-$ producing the range shown in the table. 
greater increase in $n$ (possible because $B$ has increased) could increase the agency's expected utility while reducing the average probability of its winning the cases that it brings.

2. If Elman's thesis is correct, an agency in which prosecution and adjudication are joined should be sensitive to possible criticism of a dismissal as an acknowledgment that the agency erred at the complaintissuance stage. If so, we would expect such an agency, when it does dismiss a complaint, frequently to do so without acknowledging failure to establish a violation. It may feel compelled to dismiss a complaint that cannot possibly withstand judicial review but it need not cast its dismissal in the form of a potentially damaging admission. A dismissal in which there is no acknowledgment that a violation was not established will be called a "grudging" dismissal.

I have found no grudging dismissals among the decisions of the Board. Table 10, which compares ungrudging with significant dismissals by the FTC, suggests that the grudging dismissal is an important feature of the Commission's decision-making process. That many dismissals of FTC cases, and none of NLRB cases, are grudging may appear to con-

TABLE 9

Resource Constraint and Dismissal Rate-NLRB Unfair labor Practice Cases

\begin{tabular}{|c|c|c|c|c|}
\hline Period & $\begin{array}{c}\text { Index of } \\
\text { Available } \\
\text { Resources } \\
\text { (1) }\end{array}$ & $\begin{array}{l}\text { Index of } \\
\text { Number of } \\
\text { Contested } \\
\text { Cases (2) }\end{array}$ & $\begin{array}{l}\text { Index }(1) \div \\
\text { Index (2) }\end{array}$ & $\begin{array}{c}\% \text { of } \\
\text { Contested } \\
\text { Cases } \\
\text { Dismissed }\end{array}$ \\
\hline $1935-41$ & 100 & 100 & 1.00 & .16 \\
\hline $1943-47$ & 97 & 80 & 1.21 & .13 \\
\hline $1948-52$ & $102-107$ & 121 & $.84-.88$ & .23 \\
\hline $1955-69^{a}$ & 87 & 296 & .29 & .21 \\
\hline
\end{tabular}

SOURCES. - See Table 8, supra; also U.S. Presidents, Bureau of the Budget, Budget of the United States Government, fiscal yrs. 1935-1969; Hearings before the Subcomm. of the Senate and House Comms. on Appropriations on NLRB appropriations for fiscal yrs. 1935-1969 (earlier hearings are included with the Independent Offices Appropriations Bill hearings from the 77th Cong., 2d Sess. (fiscal yr. 1943) and later are included with the Department of Labor Appropriations Bill hearings).

${ }^{a}$ The years $1955-56,1959-60,1961-62,1965-66$, and 1968-69 were used to figure the average for the period. 


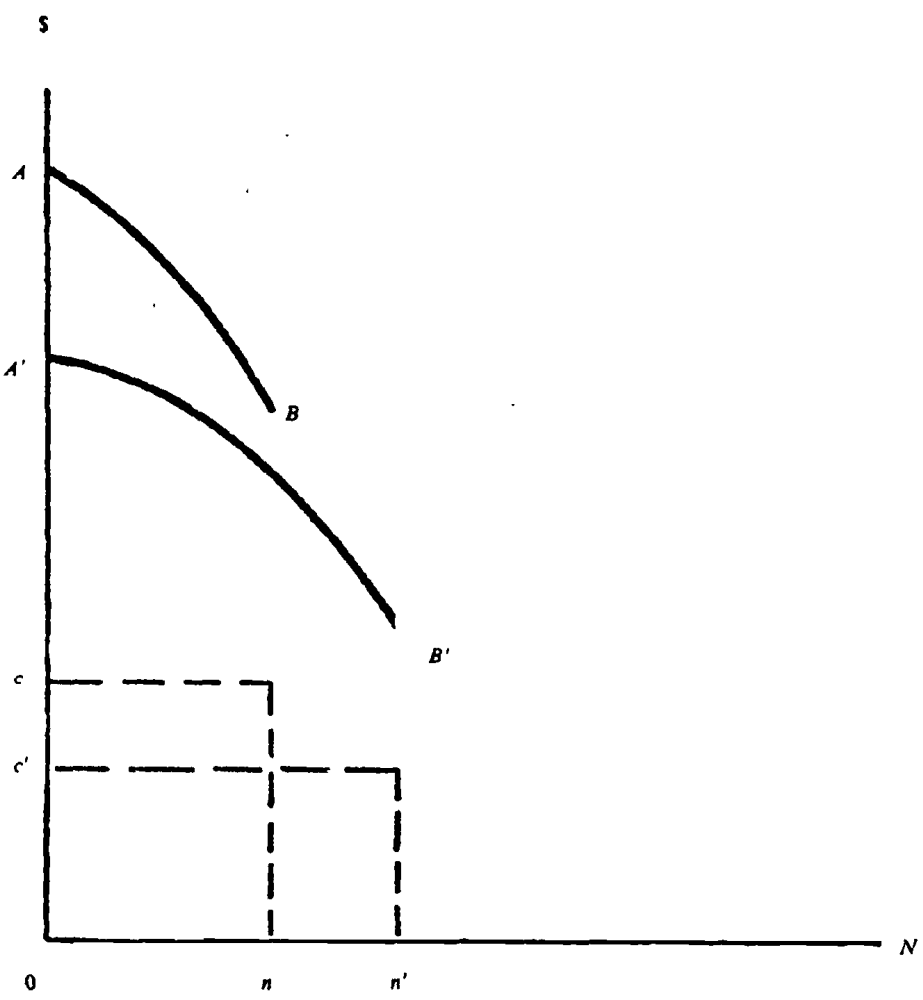

FIGURE 3

firm the Elman thesis. However, grudging dismissals were unknown at the Board even before the first separation of functions in October 1942, and are a much smaller fraction of all FTC significant dismissals after 1945 than until then. Most grudging dismissals are so classified because the Commission gave no reason for its action in dismissing, and this appears to be an aspect of the Commission's early and much criticized reticence about explaining the basis of its decisions, whether punitive or exculpatory. ${ }^{33}$ The practice of "blind" dismissals begins to wane in 1946 and disappears after 1952. In the three later periods in Table 10 only two out of 42 significant dismissals ( 24 total dismissals) are grudging.

33. See, e.g., Gerard C. Henderson, The Federal Trade Commission 334-35 (1924), and, with specific reference to the Commission's failure to state the reasons for dismissals, U.S. Atty. Gen.'s Committee on Administrative Procedure, supra note 24, at 136-37, and U.S. Atty. Gen.'s Committee on Administrative Procedure, The Federal Trade Commission 63-65 (Monograph No. 6, 1940). 
TABLE 10

FORM OF FTC DISMISSALS

\begin{tabular}{|c|c|c|c|c|c|}
\hline Period & $\begin{array}{c}\text { Total } \\
\text { Contested } \\
\text { Cases }\end{array}$ & $\begin{array}{l}\% \text { of Un- } \\
\text { grudging } \\
\text { Dismissals }\end{array}$ & $\begin{array}{l}\% \text { of } \\
\text { Total Un- } \\
\text { grudging } \\
\text { Dismissals }\end{array}$ & $\begin{array}{c}\text { Grudging } \\
\text { Dismissals } \\
\text { as a \% } \\
\text { of All } \\
\text { Significant } \\
\text { Dismissals }\end{array}$ & $\begin{array}{l}\text { Grudging } \\
\text { Total Dis- } \\
\text { missals } \\
\text { as a \% } \\
\text { of All } \\
\text { Significant } \\
\text { Dismissals }\end{array}$ \\
\hline 1938 & 60 & .10 & .03 & .50 & .71 \\
\hline 1941 & 61 & .05 & .05 & .82 & .82 \\
\hline 1943 & 32 & .09 & .06 & .63 & .71 \\
\hline 1945 & 43 & .07 & .05 & .73 & .78 \\
\hline Total $^{b}$ & $\overline{196}$ & .08 & $\overline{.05}$ &.$\overline{.69}$ & $\overline{.84}$ \\
\hline $1946-47$ & 70 & .20 & .16 & .22 & .27 \\
\hline $1949-50$ & 53 & .17 & .13 & .18 & .22 \\
\hline $1951-52$ & 62 & .23 & .18 & .07 & .08 \\
\hline $1955-56$ & 36 & .28 & .19 & .00 & .00 \\
\hline $1959-60$ & 58 & .36 & .12 & .00 & .00 \\
\hline 1965 & 34 & .29 & .24 & .17 & .20 \\
\hline Total ${ }^{b}$ & $\overline{313}$ & .25 & .16 & .11 & .15 \\
\hline
\end{tabular}

SOURCES. - See Table 5, supra.

${ }^{a}$ As defined in text.

${ }^{b}$ Or average.

3. Professor Elman's thesis implies that an agency in which prosecution and adjudication are combined will be less reluctant to dismiss a case in which legal issues predominate than one in which factual issues predominate. Since the scope of judicial review of administrative action is broader with respect to questions of law than with respect to questions of facts, an agency has little to gain by distorting the applicable law whereas it may get away with a certain amount of tendentious fact-finding.

Table 11 attempts to test this implication of the Elman thesis by comparing NLRB dismissal rates at various periods for a type of casecases in which an employer is charged with discriminating against an employee or employees because of union activities - in which factual questions, primarily motive, predominate. If the Elman thesis is correct, the dismissal rate in discrimination cases should be lower than that in all un- 
TABLE 11

Dismissal Rate-NLRB Discrimination Cases

\begin{tabular}{|c|c|c|c|c|c|}
\hline Period & $\begin{array}{c}\text { Total } \\
\text { Contested } \\
\text { Discrimina- } \\
\text { tion Cases }\end{array}$ & $\begin{array}{l}\text { Dis- } \\
\text { missals }\end{array}$ & $\begin{array}{l}\text { Complete } \\
\text { Dis- } \\
\text { missals a }\end{array}$ & $\begin{array}{c}\% \\
\text { Dismissed }\end{array}$ & $\begin{array}{c}\% \\
\text { Dismissed } \\
\text { in Entirety }\end{array}$ \\
\hline $1935-36$ & 42 & 16 & 2 & .38 & .05 \\
\hline 1938 & 29 & 23 & 8 & .79 & .28 \\
\hline 1946 & 26 & 1 & 8 & .42 & .31 \\
\hline 1947 & 17 & 6 & 2 & .35 & .12 \\
\hline Total $^{b}$ & $\overline{114}$ & $\overline{56}$ & $\overline{20}$ &.$\overline{49}$ &.$\overline{18}$ \\
\hline 1956 & 30 & 14 & 5 & .47 & .17 \\
\hline 1969 & 29 & 9 & 6 & .31 & .21 \\
\hline Total ${ }^{b}$ & $\overline{59}$ & $\overline{23}$ & $\overline{11}$ & $\overline{.39}$ & .19 \\
\hline
\end{tabular}

SOURCE. - Decisions and Orders of the National Labor Relations Board, vols. $1,8,69,72,115,178$.

a That is, of discrimination count or counts.

b Or average.

fair labor practice cases prior to the separations of functions in 1942 or 1947; a comparison with Table 6 shows that it is not. ${ }^{34}$

Table 11 also permits a comparison among dismissal rates at different stages in the Board's evolution that is unaffected by changes either in substantive law (the prohibition against employer discrimination has remained unchanged since the Wagner Act) or in the agency's mix of cases. According to Table 11 the dismissal rate has not been affected by the successive changes in the Board's structure with respect to the separation of functions.

4. It should also follow from the Elman thesis that an agency in which prosecution and adjudication are combined will, other things being equal, dismiss a smaller fraction of major cases, so classified by the amount of agency resources consumed in their prosecution, than of minor cases. Criticism of an agency for having wasted the taxpayer's money by bringing an unmeritorious case is more apt to be forthcoming and persuasive when the amount squandered is substantial.

34. The low rate of dismissals in the first year of the Board's operations, 1935-36, is consistent with data obtained for all unfair labor practice cases, but not reported in Table 5 or 6 , from the first volume of the Board's decisions. The dismissal rates in that volume are .06 (significant dismissals) and .00 (significant total dismissals). 
Unfortunately other things are not equal. Although the FTC does dismiss a higher proportion of its larger cases (the statistics were presented in Table 3), the model developed in Part I of this article suggests that there are reasons for this that have nothing to do with the presence or absence of bias. Table 3 can be made to bear on the present question, however, if another column is added-one showing the percentage of all cases, settled as well as litigated, that are dismissed (Table 12). It appears that in many periods a large fraction of the Commission's antitrust prosecutions, and hence in resource terms a large fraction of the Commission's entire enforcement activity, have not resulted in the entry of remedial orders. So marked a propensity to rule in favor of the defendant is difficult to reconcile with the Elman thesis.

5. The Elman thesis would seem to imply that the members of an agency in which prosecution and adjudication are combined would be less reluctant to dismiss a complaint that had been authorized by their predecessors in office than one they themselves had authorized. In the former case they could not properly be criticized for having initiated a case that lacked merit; in the latter case they could. The low rate of ungrudging

TABLE 12

Dismissal Rate-FTC antitrust Cases a Including Settled Cases

\begin{tabular}{lcc}
\hline \hline Period & Total Cases & $\begin{array}{c}\text { Percentage } \\
\text { Dismissed }\end{array}$ \\
\hline 1938 & 19 & .05 \\
1941 & 26 & .35 \\
1943 & 8 & .38 \\
1945 & 9 & .22 \\
$1946-47$ & 11 & .27 \\
Total $^{c}$ & 73 & .25 \\
$1949-50$ & 16 & .25 \\
$1951^{-52}$ & 15 & .07 \\
$1955-56$ & 32 & .09 \\
$1959-60$ & 21 & .10 \\
1965 & 34 & .26 \\
Total $^{c}$ & 118 & .16 \\
\hline
\end{tabular}

Source. - See Table 3, supra.

${ }^{a}$ Excluding cases brought exclusively under one of the minor Robinson-Patman Act amendments. See note 10, supra.

b Significant total dismissals only, as defined in text.

c Or average. 
dismissals disclosed by Table 10 for the period up to 1945 may appear to support this hypothesis, for it was a period in which nearly all the cases decided by the members of the Commission had been authorized by the very same members. ${ }^{35}$ In subsequent periods the average tenure of the members of the Commission is much shorter.

But an inference that members of the Commission are more prone to dismiss complaints of their predecessors than their own complaints cannot in fact be drawn from these data. As explained earlier, the decline in the proportion of grudging dismissals appears to reflect the gradual adoption of a policy of stating reasons for dismissing a complaint rather than the length of service of the commissioners in relation to the cases they decide. If we ignore, therefore, whether a dismissal is grudging or ungrudging and consider only whether it is significant, we find that the dismissal rate is no higher after 1945, despite the reduction in the commissioners' average length of service.

Further evidence is presented in Tables 13 through 15, which analyze the later periods in detail. The last column in each box in Table 13 shows the percentage dismissed of cases in which all five members of the Commission who decided the case had also been members when the complaint was issued, cases in which four members of the Commission who decided the case had also been members when the complaint was issued, and so on down to zero (i.e., none of the incumbents were members of the Commission when the complaint was issued), in various periods. If members of the Commission are reluctant to dismiss their own complaints but less reluctant to dismiss those of their predecessors the percentage of dismissals should increase as we move down the columns.

If dismissals are grouped according to whether three or more or two or fewer commissioners deciding the case were members of the Commission when the complaint was issued, the dismissal rate is indeed higher in the second group (Table 14). The difference, however, is not statistically significant. Moreover, contrary to the prediction derived from the Elman thesis, the highest rate of dismissal is found where all five members of the Commission were members when the complaint was issued (the number of cases, however, is too small to be significant); and the rate of dismissal is the same where three members of the Commission when the case was decided were members when the complaint was issued as it is where only one present member of the Commission was also a member when the complaint was issued.

35. In 1938 the most junior member of the Commission had sat for three years and only two cases decided that year had been instituted prior to his appointment. In 1941 the most junior member had sat for six years; the figure is eight years for 1943 and ten for 1945. 


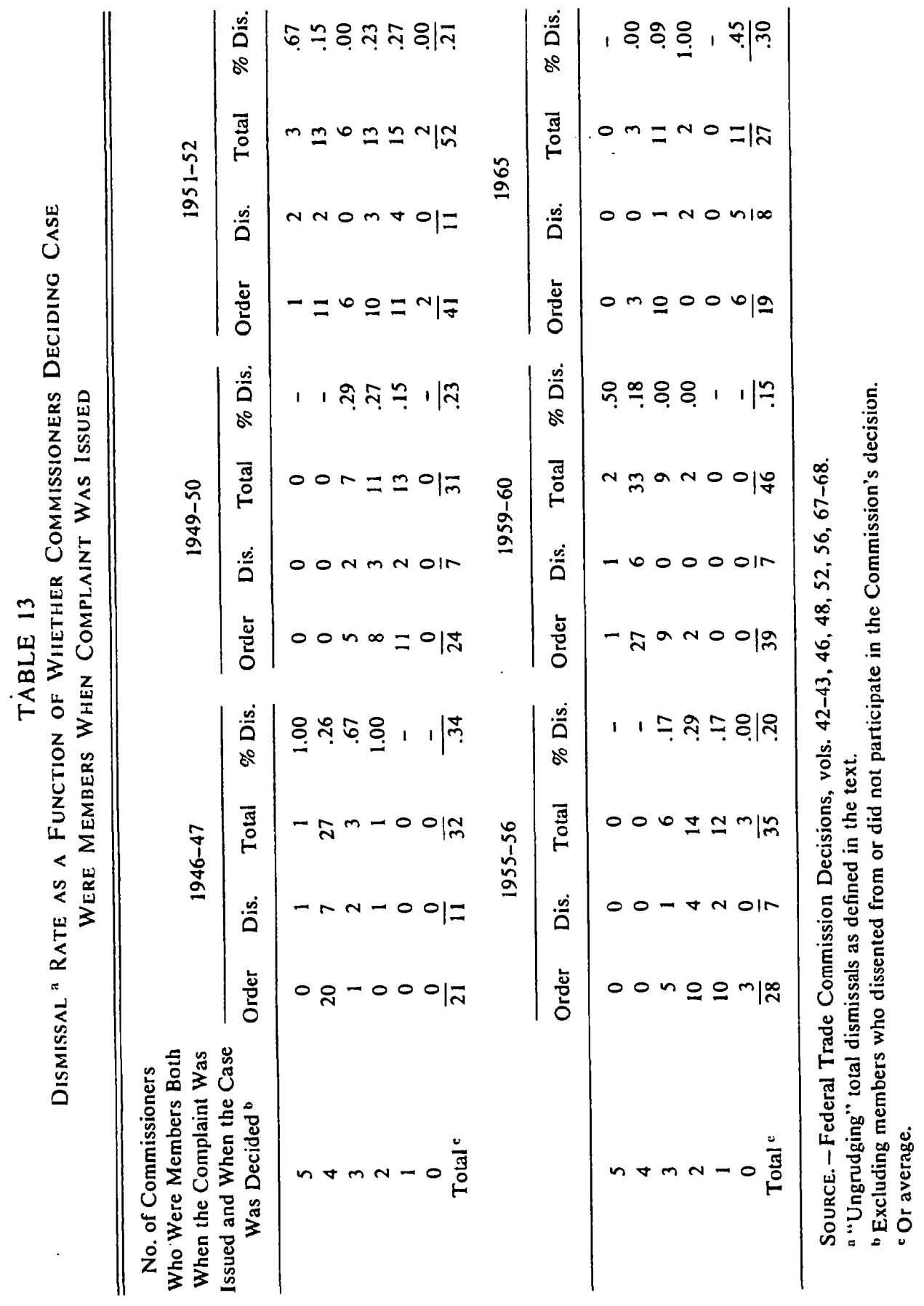


TABLE 14

Dismissal a Rate as a Function of Whether Commissioners

Deciding Case Were Members When Complaint Was IssuedSUMMARY OF TABLE 13

No. of Commissioners

Who Were Members Both When the Complaint Was Issued and When the Case Was Decided ${ }^{\text {b }}$

\begin{tabular}{rrrr}
\multicolumn{4}{c}{ All Periods } \\
\hline Order & Dis. & Total & \% Dis. \\
\hline 2 & 4 & 6 & .67 \\
61 & 15 & 76 & .20 \\
36 & 6 & 42 & .14 \\
30 & 13 & 43 & .30 \\
32 & 8 & 40 & .20 \\
11 & 5 & 16 & .31 \\
$\frac{5}{172}$ & $\frac{5}{51}$ & $\frac{.23}{.23}$ & .20 \\
99 & 25 & 124 & .26 \\
73 & 26 & 99 &
\end{tabular}

SOURCE. - Table 13, supra.

a "Ungrudging" total dismissals as defined in the text.

${ }^{b}$ Excluding members who dissented from or did not participate in the Commission's decision.

c Or average.

Tables 13 and 14 count only commissioners voting with the majority, either to dismiss or to enter a remedial order. The votes of dissenters are treated separately in Table 15. If members of the Commission were more reluctant to dismiss their own complaints than their predecessors', then we would expect old members (members both when the complaint was issued and when the case was decided) to dissent more frequently when the majority voted to dismiss the complaint than when the majority voted to enter an order. Table 15 indicates, however, that old members voted to dismiss the complaint - their complaint, as it were - 13 times when the majority voted to enter a remedial order, and voted only four times to enter an order when the majority voted to dismiss the complaint. ${ }^{36}$

36. It is of course possible for an "old" member voting against the complaint to have dissented from the original action of the Commission in issuing the complaint, in which event his later vote would be no evidence of open-mindedness. Unfortunately, data on vot- 
TABLE 15

Votes of DisSenting FTC COMmissioners - 1946-65

\begin{tabular}{|c|c|c|c|c|c|}
\hline \multirow[b]{3}{*}{ Period } & \multirow[b]{3}{*}{ Number } & \multicolumn{4}{|c|}{ Nature of Vote } \\
\hline & & \multicolumn{2}{|c|}{$\begin{array}{l}\text { For Issuance of } \\
\text { Remedial Order }\end{array}$} & \multicolumn{2}{|c|}{$\begin{array}{c}\text { For Dismissal of } \\
\text { Complaint }\end{array}$} \\
\hline & & $\begin{array}{c}\text { By } \\
\text { Commissioner } \\
\text { Who Was } \\
\text { Member } \\
\text { When Com- } \\
\text { plaint Was } \\
\text { Issued }\end{array}$ & $\begin{array}{c}\text { By } \\
\text { Commissioner } \\
\text { Who Was Not } \\
\text { Member } \\
\text { When Com- } \\
\text { plaint Was } \\
\text { Issued }\end{array}$ & $\begin{array}{c}\text { By } \\
\text { Commissioner } \\
\text { Who Was } \\
\text { Member } \\
\text { When Com- } \\
\text { plaint Was } \\
\text { Issued }\end{array}$ & $\begin{array}{c}\text { By } \\
\text { Commissioner } \\
\text { Who Was Not } \\
\text { Member } \\
\text { When Com- } \\
\text { plaint Was } \\
\text { Issued }\end{array}$ \\
\hline $1946-47$ & 3 & 3 & - & - & - \\
\hline $1949-50$ & - & - & - & - & _- \\
\hline $1951-52$ & 3 & - & - & 3 & - \\
\hline $1955-56$ & 9 & - & - & 9 & - \\
\hline $1959-60$ & - & - & - & - & - \\
\hline 1965 & 12 & 1 & 6 & 1 & 4 \\
\hline Total & $\overline{27}$ & $\overline{4}$ & $\overline{6}$ & $\overline{13}$ & $\overline{4}$ \\
\hline
\end{tabular}

Source. - See Table 13, supra.

6. If the combination of prosecution and adjudication makes an agency reluctant to dismiss unmeritorious complaints and thus prone to enter unjustified orders, one would expect the orders of such an agency to be reversed more frequently on judicial review than the orders of an agency in which the functions are separated. Table 16 seeks to test this hypothesis by comparing, for a few randomly selected periods, the results of judicial review of FTC cease and desist orders and orders in NLRB unfair labor practice cases. Employer discrimination cases are reported separately to facilitate comparison between the preseparated and the separated Board.

Table 16 shows not only that the FTC has fared consistently better on judicial review than the Board, but also (and more pertinently, since according to our model many factors apart from bias must influence an

ing at the complaint-issuance stage are unavailable. It should be noted, however, that under the Elman view the commissioner who voted against issuing the complaint in the first place would still feel considerable pressure to enter a cease and desist order after the trial in order to protect the agency against charges of having wasted the taxpayer's money and in order to prevent the demoralization of the staff. 


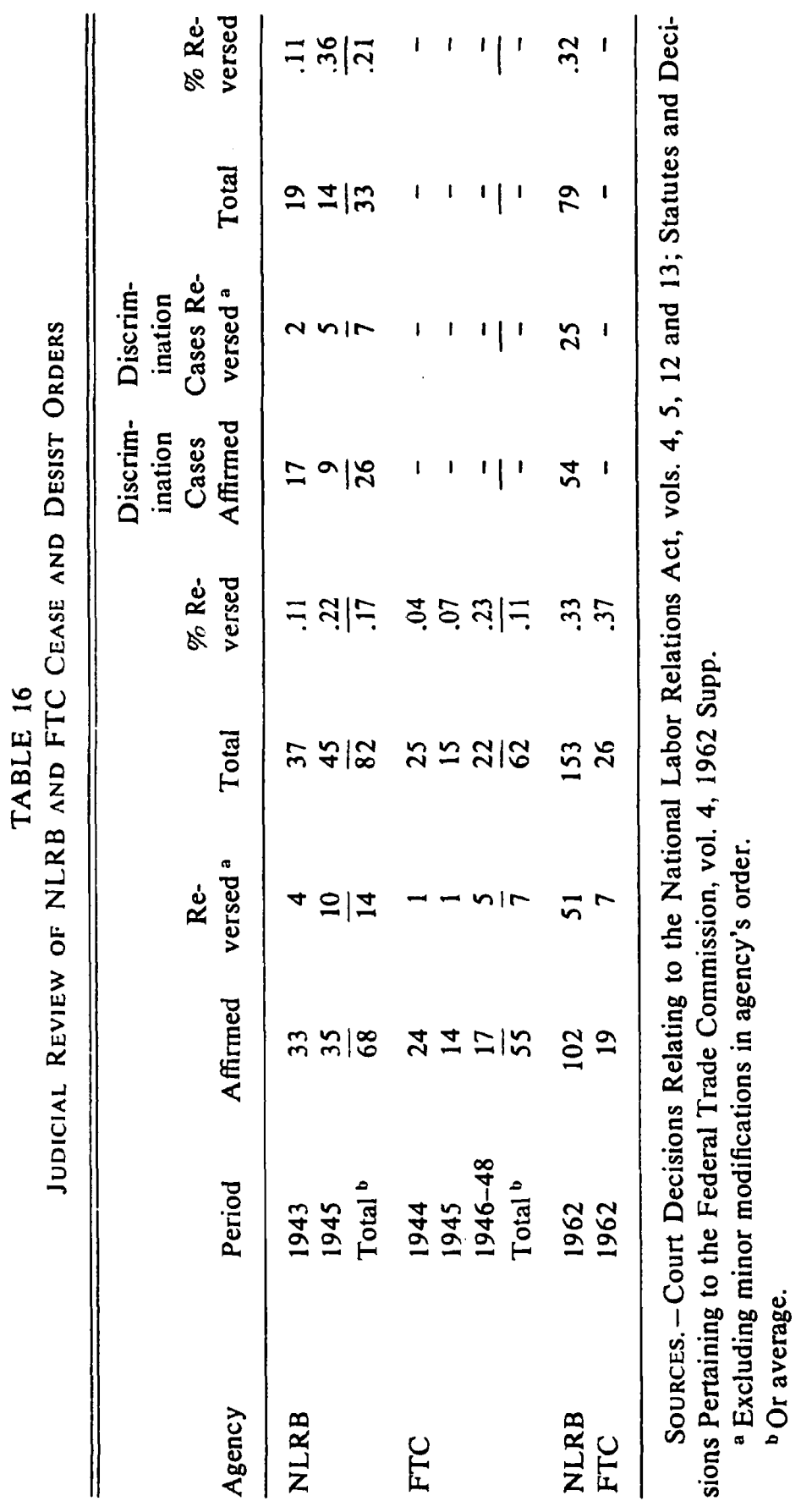


agency's $\dot{p}$ on judicial review) that the Board's record has actually worsened since separation, both generally and with respect to discrimination cases alone. However, Table 16 also reveals secular changes in the outcome of judicial review of agency action that cannot be ascribed to the combination or separation of functions and that may conceal the effect of separation.

7. Finally, an agency in which prosecution and adjudication are combined is, under the Elman thesis, one much concerned about being criticized for dismissing complaints but relatively unconcerned about its record on judicial review. (Were it greatly concerned about its court record it would dismiss all doubtful cases in order to minimize the danger of being reversed by a reviewing court.) This model would be more persuasive were there evidence that an agency like the FTC or NLRB was judged, by those with power over the agency, more by its internal batting average than by its success or failure in the courts. Some places to look for such evidence are the agencies' annual reports, where the agency boasts of its successful performance, presumably using criteria of success persuasive to its intended audience; the agencies' annual appropriation hearings before the House and Senate appropriation subcommittees; and appraisals of the agencies' performance by critics or supporters. A search of these sources reveals, however, many more references to the agency's record on judicial review than to the rate at which either the FTC or the NLRB dismisses complaints.

In one respect, though, dismissals clearly could affect an agency's performance. Congress, the agencies, and their critics all seem greatly concerned with the size of the agency's work load as measured by such quantitative indicia as the number of charges filed with the agency, the number of complaints issued, and the number of decisions. The routine argument advanced for a larger appropriation is that the agency's work load has grown faster than its budget, and an increase in work load is difficult to demonstrate unless some quantitative change can be pointed to. The routine criticism of an agency is that its budget is excessive in relation to its present quantity of work. The effect of a dismissal may be to compel the agency's staff, in similar future cases, to investigate more thoroughly before recommending a complaint and to present more evidence of violation at trial - in short, to expend additional resources in the prosecution of the case. This will reduce the number of cases it can bring with reasonable prospect of success.

Such a process can be seen at work in the FTC in the middle and late 1960s. As Table 3 shows, in 1965 the Commission dismissed 60 per cent of its contested antitrust cases. Many of these decisions established higher standards for proving violations of law than had previously been 
applied by the Commission. By 1969 we find the American Bar Association's Commission to Study the Federal Trade Commission blasting the Commission for a precipitous decline in its work load as measured by number of investigations, decisions, and other conventional quantitative criteria of activity ${ }^{37}$ The causation is complex but it would seem that one of the reasons for the Commission's decline ${ }^{38}$ in number of cases was its change of policy, reflected in the dismissals of the middle 1960s, in the direction of more exacting standards of proof.

This history may influence the Commission's future decisions whether or not to dismiss complaints, in circumstances where a dismissal would increase the difficulty of proving a violation. But it is at least as significant, in appraising the Elman thesis, to observe that the Commission in 1965 was apparently not deterred by such a prospect from dismissing major cases with great frequency.

\section{Why Were Prosecution and adjudication Separated at THE BOARD AND NOT AT THE COMMISSION?}

The results of our inquiry into whether the combination of prosecution and adjudication biases an agency's adjudication, although hardly definitive, suggest that it does not. If so, one may wonder why the Board effected a limited separation in 1942, why Congress extended and formalized the separation, apparently at some cost in efficiency, ${ }^{39}$ in 1947 , and how the FTC has escaped serious pressure for some form of separation.

The congressional hearings preceding enactment of the Taft-Hartley Act developed no firm evidence of bias in adjudication traceable to the combination of functions. ${ }^{40}$ And if separation was legislated because combination was thought inherently unfair, it is hard to understand why the combination of functions in the FTC has not only persisted but escaped sustained controversy.

The probable explanation for separation at the Labor Board lies not in the merits of the issue but in its politics. The opposition of the business community to the Wagner Act and its enforcing agency ${ }^{11}$ was better or-

37. See ABA Comm'n to Study the Federal Trade Commission, supra note 9, at 16-26.

38. Which the ABA Commission, however, overstated. See Richard A. Posner, A Statistical Study of Antitrust Enforcement, supra note 10, at 370.

39. See 2 Kenneth Culp Davis, Administrative Law Treatise $\S 13.05$, pp. 206-11.

40. See id. at $\$ 13.05$, pp. 204-5.

41. This opposition is described in Harry A. Millis \& Emily Clark Brown, From the Wagner Act to Taft-Hartley - A Study of National Labor Policy and Labor Relations 38191 (1950). 
ganized, more vocal, and more tenacious than the business community's opposition to the FTC and the statutes it enforces has ever been. The costs imposed by the Board on business were probably greater than those imposed by the FTC - this might explain why greater resources were marshaled against the Board than against the Commission. Probably, too, it is easier to organize employers as an effective political pressure group than the diffuse victims of FTC prosecution. At all events, within 12 years of the passage of the Wagner Act the opponents of that Act and of the Board were able, in the Taft-Hartley Act, to effect a major overhaul of the law. Charges of unfairness are a conventional refrain in the litany of political controversy and once the Wagner Act was up for a thorough overhaul it was relatively easy to amend the provisions of the Act relating to the structure of enforcement as well as the substantive law provisions; thire has never been a comparable overhaul of the Federal Trade Commisision Act. That the separation of functions apparently imposed at least short-term costs in the form of lowered efficiency due to problems of coordination between the Board and the General Counsel provides a sufficient explanation why the Board's opponents should have wanted to bring about a separation of the functions regardless of the actual merits of such a step.

What the last point may suggest is that administrative regulation can perhaps best be understood when elements of the effective-politicalgroup and rational-utility-maximizing models of administrative agency behavior are combined.

\section{APPENDIX}

Proof That the Condition for Litigation

Cannot Be Satisfied If $s=s^{\prime}, k>1$, and $r=1$

so

$$
\frac{e c}{c+c^{\prime}}+\frac{e^{\prime} c^{\prime}}{c^{\prime}+c}=1
$$

$$
e=\frac{\sqrt{e^{\prime} s^{\prime}}\left(1-e^{\prime}\right)}{\sqrt{c}}+e^{\prime} \text {. }
$$

Substituting this equation into inequality (15), the condition for litigation becomes

$$
\frac{\sqrt{e^{\prime} s^{\prime}}\left(1-e^{\prime}\right)}{\sqrt{c}}+e^{\prime}>\frac{s^{\prime} e^{\prime}}{s}\left[\frac{c^{\prime}}{s^{\prime}}\left(\frac{1-e^{\prime}}{\sqrt{e^{\prime}}}\right)+2-\frac{1}{k}\right] \text {. }
$$

Since $s=s^{\prime}$, this can be simplified to 


$$
\frac{\sqrt{e^{\prime} s^{\prime}}\left(1-e^{\prime}\right)}{\sqrt{c}}+e^{\prime}>\frac{\sqrt{s^{\prime} e^{\prime}}\left(1-e^{\prime}\right)}{\sqrt{c}}+e^{\prime}\left(2-\frac{1}{k}\right) \text {. }
$$

Subtracting the first term on the left-hand side of the inequality from both sides, we have

$$
e^{\prime}>e^{\prime}\left(2-\frac{1}{k}\right)
$$

Since $k>1$, the right side must exceed the left for any value of $e^{\prime}$, and the condition for litigation cannot be satisfied.

TABLE A1

Ratio of Significant Dismissals to Remedial Orders, Department of Justice Antitrust Division and FTC Antitrusta Cases

\begin{tabular}{|c|c|c|c|c|c|}
\hline Agency & $\begin{array}{c}\text { Period } \\
\text { in Which } \\
\text { Case Was } \\
\text { Brought }\end{array}$ & $\begin{array}{c}\text { Remedial } \\
\text { Order }\end{array}$ & $\begin{array}{c}\text { Dis- } \\
\text { missal }\end{array}$ & Total & $\begin{array}{l}\text { \% Dis- } \\
\text { missed }\end{array}$ \\
\hline \multicolumn{6}{|l|}{ Antitrust } \\
\hline \multirow[t]{7}{*}{ Division } & $1935-39$ & 15 & 12 & 27 & .44 \\
\hline & $1940-44$ & 51 & 50 & 101 & .50 \\
\hline & $1945-49$ & 26 & 28 & 54 & .52 \\
\hline & $1950-54$ & 38 & 22 & 60 & .37 \\
\hline & $1955-59$ & 58 & 18 & 76 & .24 \\
\hline & $1960-64$ & 63 & 31 & 94 & .33 \\
\hline & Total $^{b}$ & $\overline{251}$ & $\overline{161}$ & $\overline{412}$ & $\overline{.39}$ \\
\hline \multirow[t]{7}{*}{ FTC } & $1935-39$ & 50 & 36 & 86 & .42 \\
\hline & $1940-44$ & 48 & 23 & 71 & .32 \\
\hline & $1945-49$ & 20 & 12 & 32 & .38 \\
\hline & $1950-54$ & 14 & 10 & 24 & .42 \\
\hline & $1955-59$ & 35 & 22 & 57 & .39 \\
\hline & $1960-64$ & 23 & 14 & 37 & .38 \\
\hline & Total $^{\mathrm{b}}$ & $\overline{190}$ & $\overline{117}$ & $\overline{307}$ & $\overline{.38}$ \\
\hline
\end{tabular}

(Contested Cases Only)

Source. - Richard A. Posner, A Statistical Study of Antitrust Enforcement, 13 J. Law \& Econ. 365, 376 (Table 6), 379 (Table 9), 381 (Table 11), 382 (Table 12).

${ }^{a}$ Excluding cases brought exclusively under the minor Robinson-Patman Act amendments. See note 10 , supra.

${ }^{b}$ Or average. 
TABLE A2

NlRb Employer Unfair labor Practice Cases Closed at Precomplaint Stage

\begin{tabular}{|c|c|c|c|c|}
\hline Period & $\begin{array}{c}\text { Cases } \\
\text { Pending }\end{array}$ & $\begin{array}{l}\text { \% With- } \\
\text { drawn or } \\
\text { Dismissed }\end{array}$ & $\begin{array}{l}\% \text { With- } \\
\text { drawn or } \\
\text { Dismissed- } \\
\text { Excluding } \\
\text { Charges } \\
\text { Filed by } \\
\text { Individuals }\end{array}$ & $\begin{array}{c}\% \text { of } \\
\text { Charges } \\
\text { Filed by } \\
\text { Individuals }\end{array}$ \\
\hline $1935-36$ & 865 & .32 & N.A. & N.A. \\
\hline $1936-37$ & 3,124 & .21 & N.A. & N.A. \\
\hline $1937-38$ & 8,213 & .31 & .29 & .08 \\
\hline $1938-39$ & 7,132 & .25 & .24 & .09 \\
\hline $1939-40$ & 6,836 & .33 & .30 & .11 \\
\hline $1940-41$ & 6,981 & .30 & .28 & .09 \\
\hline Total a & $\overline{33,151}$ & .29 & $\overline{.28}$ & $\overline{.09^{b}}$ \\
\hline $1943-44$ & 3,896 & .42 & N.A. & .09 \\
\hline $1944-45$ & 3,633 & .42 & N.A. & .09 \\
\hline $1945-46$ & 5,126 & .40 & N.A. & .06 \\
\hline $1946-47$ & 6,457 & .45 & N.A. & .06 \\
\hline Total a & $\overline{19,112}$ &.$\overline{42}$ & - &.$\overline{.07}$ \\
\hline $1948-49$ & 5,543 & .43 & N.A. & .38 \\
\hline $1949-50$ & 6,635 & .43 & N.A. & .33 \\
\hline $1950-51$ & 8,504 & .35 & N.A. & .33 \\
\hline $1951-52$ & 6,676 & .45 & N.A. & .27 \\
\hline Total ${ }^{a}$ & $\overline{27,358}$ & $\overline{.41}$ & $\overline{-}$ & $\overline{.33}$ \\
\hline $1955-56$ & 5,326 & .57 & N.A. & .36 \\
\hline $1959-60$ & 11,121 & .54 & N.A. & .46 \\
\hline $1961-62$ & 12,186 & .50 & N.A. & .38 \\
\hline $1965-66$ & 15,632 & .44 & N.A. & .29 \\
\hline $1968-69$ & 17,559 & .47 & N.A. & .34 \\
\hline Total a & $\overline{61,824}$ & $\overline{49}$ & $\overline{-}$ & $\overline{.36}$ \\
\hline
\end{tabular}

SoURCE. - See Table 8, supra.

a Or average.

bxcluding 1935-1937. 


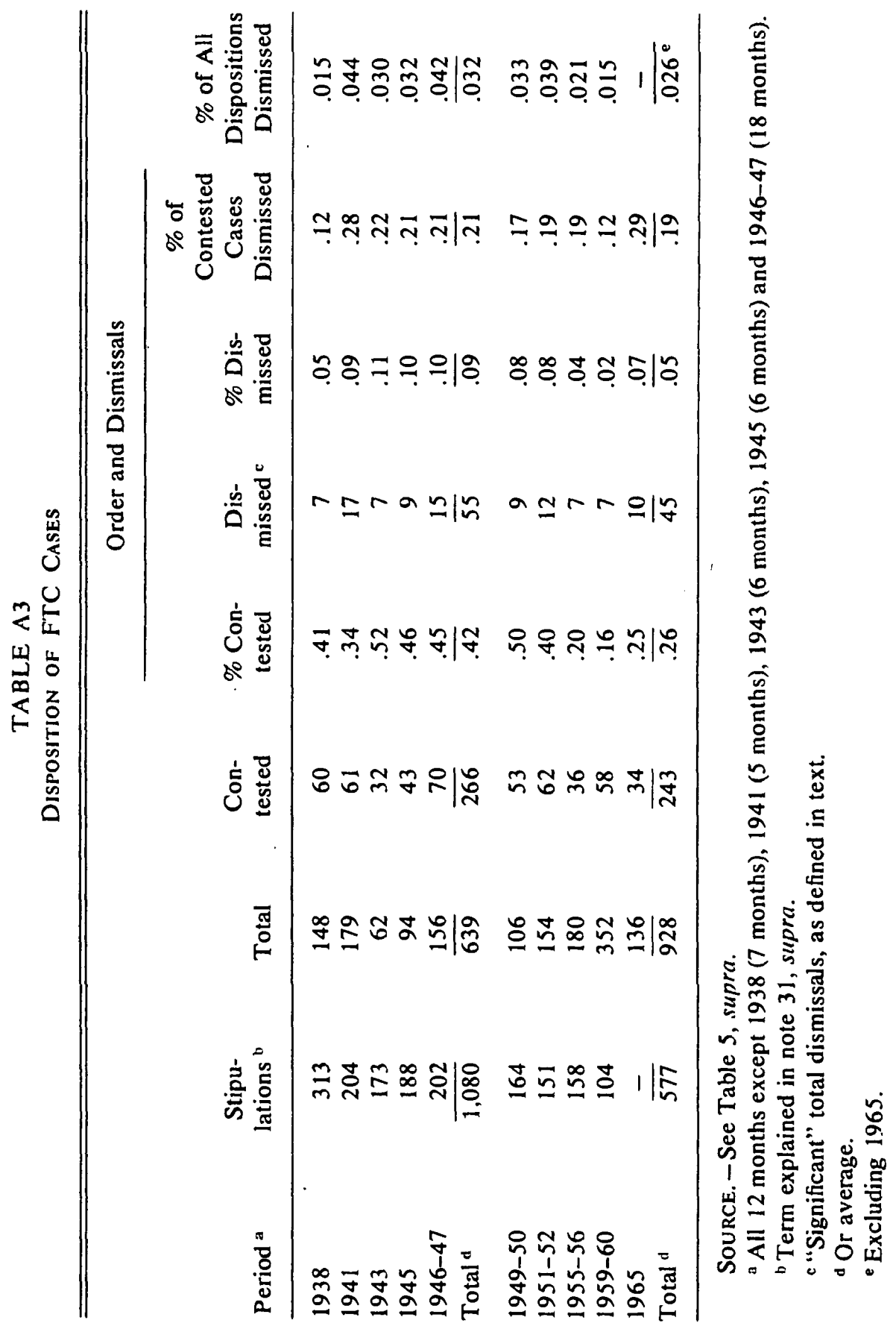

